\title{
Real Estate Investment Trusts: A Review of the Financial Economics Literature
}

\author{
JOHN B. CORGEL \\ Director, Center for Hospitality Research, School of Hotel Administration, 182 Statler Hall, Cornell \\ University, Ithaca, NY 14853 \\ WILLARD MCINTOSH \\ Senior Vice President, Director of Research, MIG Realty Advisors, Inc., West Palm Beach, FL 33401 \\ STEVEN H. OTT \\ Director, Center for Real Estate Studies, College of Business and Economics, Department of Finance, \\ University of Kentucky, Lexington, KY 40506
}

\begin{abstract}
This paper is a survey of the literature on Real Estate Investment Trusts, commonly known as REITs. The literature is separated into three major research topics: investment decisions, financing decisions, and return and risk issues. The central papers addressing each of these optics are described and their results are summarized. Suggestions for further research also are provided.
\end{abstract}

Since their beginnings in 1960, shares of Real Estate Investment Trusts, commonly known as REITs, have been publicly traded. The general availability of daily returns data for REITs, which hold only real estate-related assets, have given researchers unique opportunities to study issues in real estate financial economics. For example, access to returns data have allowed researchers to 1) perform event studies that show how the value of REIT shares react to significant public announcements, 2) study the return and risk relationship of securitized real estate and draw comparisons to the performance of unsecuritized real estate, 3) study the performance of REITs relative to other asset classes, 4) study the effects of inclusion of securitized and unsecuritized real estate in investment portfolios, and 5) examine agency problems in real estate and REITs. Additionally, the unique institutional and tax characteristics of REITs provide opportunities to isolate and study issues central to corporate finance, such as dividend policy and capital structure.

The dimensions of the REIT literature have expanded greatly in recent years. The goal of this paper is to organize this literature and summarize the main findings. The scope of the task is narrowed by concentrating on papers written since 1980 that relate directly to financial economics that introduce REITs as special cases. An exception is made if a pre-1980 paper provides a foundation for the current literature. We review both published and unpublished research and discuss those papers that are the most relevant and representative of the major topical areas of research identified for this review.

The REIT literature is divided into three major topical areas: investment decisions, financing decisions, and return and risk issues affecting REITs. To better relate the papers to one another, we further divide the literature into subtopics. The remaining sections of the paper follow the organizational structure just described. The next section is an overview of the institutional background of REITs. Section 2 is a review of studies on the investment 
decisions and REITs, while Section 3 covers the literature on REIT financing decisions. Section 4 reviews the literature on the return and risk issues. We conclude with suggestions for further research in Section 4. Note that Table 2, which summarizes the literature reviewed in this article, also is in the final section.

\section{Institutional background and a brief history of REITs ${ }^{1}$}

REITs are closed-end investment companies with publicly traded stock. They serve as financial intermediaries to facilitate the flow of funds from investors to the real estate sector of the economy. Some of the many investors who demand real estate use REITs as a way to invest in the real estate class for return and portfolio objectives while retaining the investment liquidity provided by the secondary market for REIT shares.

The REIT organizational form was authorized in 1960 when federal legislation provided tax exemptions for "qualified REITs" that satisfy certain requirements. To be qualified, REITs must meet the following criteria: 1) $75 \%$ of all assets must consist of mortages, real estate equities, case or government securities; 2 ) at least $95 \%$ of taxable income must be distributed to REIT shareholders each year; 3) at least $75 \%$ of gross income must be derived from rents, mortages, and gains from the sale of real estate; and 4) real property must not be held primarily for sale in the ordinary course of business. ${ }^{2}$ Qualified REITs pass through income, untaxed at the organization level, to the owners in much the same way as partnerships, although owners do not receive the benefit of pass through of tax losses. Boards of directors or trustees administer REITs on behalf of the owners, while day-to-day management is performed either internally or externally. Internally administered REITs employ their own acquisition and asset management staffs. When REITs are externally managed, outside advisors perform these services and bill the organization for expenses.

The National Association of Real Estate Investment Trusts (NAREIT) classifies REITs into three categories: 1) equity REITs that have direct ownership of income producing real estate, principally office buildings, shopping centers, warehouses, and apartments; 2) mortgage REITs that consist of investments in debt instruments secured by mortgages; and 3 ) hybrid REITs that combine both direct ownership of real estate and mortgage debt. ${ }^{3}$ Equity REITs hold $45 \%$, mortgage REITs hold $46 \%$, and hybrid REITs hold $9 \%$ of total REIT assets (NAREIT, 1993). ${ }^{4}$

The growth of REIT assets was slow from 1960 to 1968 after which organizers and investors began to understand the advantages of REITs. With REIT assets of less than $\$ 1$ billion in 1968 , assets grew to $\$ 21$ billion by 1975 . Most of the growth during this period was due to investment by mortgage REITs; however, during the mid-1970s many of these REITs went into bankruptcy and liquidation due to poor loan underwriting and rising interest rates. Following a period of consolidation, REIT assets recovered to nearly $\$ 17$ billion by 1985 .

The Tax Reform Act of 1986, which included the Real Estate Investment Trust Modernization Act, spurred considerable growth in REIT assets. The legislation contained provisions that provide REITs greater management flexibility and a less restrictive tax environment. Also, changes in depreciation allowances and passive loss rules increased the attractiveness of REITs relative to limited partnerships. Consequently, REITs are again popular real estate investment vehicles for certain institutional, corporate, ${ }^{5}$ and individual investors. ${ }^{6}$

Despite recent asset growth, REIT assets only represent a small percentage of the total stock of U.S. real estate. The net asset value of the 206 qualified REITs as reported by 
Table 1. Historic average annual returns (percentage): REITs, S\&P 500, and unsecuritized real estate investments.

\begin{tabular}{|c|c|c|c|c|c|c|c|}
\hline & \multicolumn{4}{|c|}{ REITs } & \multirow{2}{*}{$\begin{array}{l}\text { Equity w/o } \\
\text { Health Care }\end{array}$} & \multirow[b]{2}{*}{ S\&P 500} & \multirow{2}{*}{$\begin{array}{l}\text { Russell- } \\
\text { NCREIF }\end{array}$} \\
\hline & All & Equity & Mortgage & Hybrid & & & \\
\hline 1972 & 11.19 & 8.01 & 12.17 & 11.41 & 8.01 & 18.90 & - \\
\hline 1973 & -27.22 & -15.52 & -36.26 & -23.37 & -15.52 & -14.77 & - \\
\hline 1974 & -42.23 & -21.40 & -45.32 & -52.22 & -21.40 & -26.39 & - \\
\hline 1975 & 36.34 & 19.30 & 40.79 & 49.92 & 19.30 & 37.16 & - \\
\hline 1976 & 48.97 & 47.59 & 51.71 & 48.19 & 47.59 & 23.57 & - \\
\hline 1977 & 19.08 & 22.42 & 17.82 & 17.44 & 22.42 & -7.41 & - \\
\hline 1978 & -1.64 & 10.34 & -9.97 & -7.29 & 10.34 & 6.39 & - \\
\hline 1979 & 30.53 & 35.86 & 16.56 & 33.81 & 35.86 & 18.20 & - \\
\hline 1980 & 28.02 & 24.37 & 16.80 & 42.46 & 24.37 & 32.27 & 18.07 \\
\hline 1981 & 8.58 & 6.00 & 7.07 & 12.23 & 6.00 & -5.01 & 16.86 \\
\hline 1982 & 31.64 & 21.60 & 48.64 & 29.56 & 21.60 & 21.94 & 9.44 \\
\hline 1983 & 25.47 & 30.64 & 16.90 & 29.90 & 30.64 & 22.39 & 13.31 \\
\hline 1984 & 14.82 & 20.93 & 7.26 & 17.25 & 20.93 & 6.10 & 13.04 \\
\hline 1985 & 5.92 & 19.10 & -5.20 & 4.23 & 19.10 & 31.07 & 10.10 \\
\hline 1986 & 19.18 & 19.16 & 19.21 & 18.75 & 16.41 & 18.56 & 6.53 \\
\hline 1987 & -10.67 & -3.64 & -15.67 & -17.58 & -4.48 & 5.10 & 5.67 \\
\hline 1988 & 11.36 & 13.49 & 7.30 & 6.60 & 15.75 & 16.83 & 7.04 \\
\hline 1989 & -1.81 & 8.84 & -15.90 & -12.14 & 4.64 & 31.37 & 6.21 \\
\hline 1990 & -17.35 & -14.84 & -18.37 & -28.21 & -23.62 & -3.27 & 1.47 \\
\hline 1991 & 35.68 & 35.70 & 31.83 & 39.16 & 29.42 & 30.40 & -6.08 \\
\hline 1992 & 12.18 & 14.59 & 1.92 & 16.59 & 20.66 & 8.42 & -5.03 \\
\hline $1993^{1}$ & 11.38 & 12.14 & 8.84 & 10.50 & 12.89 & 2.21 & - \\
\hline
\end{tabular}

1. Through February 26, 1993.

Sources: NAREIT, Chase Investment Performance Digest, Russell-NCREIF, and Realty Stock Review, March 29, 1993.

NAREIT (1993) is approximately $\$ 48$ billion, which is between one and two percent of total U.S. real estate wealth. The total mortgage portfolio for REITs is nearly $\$ 25$ billion and traded REITs have an equity capitalization of about $\$ 24$ billion. The 20 largest REITs represent $70 \%$ of the total (Gilberto, 1992).

Table 1 shows that REIT performance has varied greatly since 1972. Surprisingly, the returns on all REITs were negative only for three years from 1972 through 1986. Poor performance was recorded between 1986 and 1990, but since 1990, REITs have outperformed the S\&P 500 and substantially outperformed the Russell NCREIF index of unsecuritized real estate.

\section{Review of the literature on investment issues}

The objective of this section is to review the literature on investment decisions, which includes studies in which REIT data are used, that focus on prices and values without regard to financing decisions of REITs. The literature on financing decisions and REITs is reviewed in the next section. This section of the review is organized by separating the literature into four categories: 1) REITs as real estate and common stocks, 2) REIT asset acquisitions and dispositions, 3) restructing of REITs, and 4) asset market information and REIT prices. 


\subsection{Are REITs real estate or stocks?}

A good starting point for reviewing the REIT financial economics literature is to appropriately characterize REITs as financial assets. This appears to be an unambiguous task. The returns on REITs should behave as do returns on real estate because legally qualified REITs must hold high percentages of real estate-related assets. Yet, REITs are securitized claims to real estate, which introduces a low-transaction-cost, trading-market dimension not present in the unsecuritized (i.e., real asset) market.

Even before October 1987 when average REIT prices declined in one month by 14 percent, ${ }^{8}$ there was general skepticism that REITs are not real estate, but instead hybrid financial assets that embody the economic characteristics of the underlying real asset market coupled with the volatility of the stock market. During the same year as the stock market crash, Goldman Sachs published a multi-part study of real estate returns and risks (Ross and Zisler, 1987a, 1987b). ${ }^{9}$ One aspect of the study was to select an appropriate return index upon which to base the analysis. The NAREIT, equity REIT index (EREIT) is considered along with alternative, unsecuritized market indexes. Because of its high volatility, Ross and Zisler conclude, "While EREIT is a true return series, it is not a true measure of the returns on the underlying assets in the fund's equity real estate" (1991, p. 181). The appraisal-based return series also are found to be unsatisfactory measures of the "true" return on real estate. Ross and Zisler conclude that the true return index for real estate lies somewhere between available securitized and unsecuritized real estate return indexes. Others (Goetzman and Ibbotson, 1990) conjecture that smooth series of appraisal-based returns are closer to the evolution of true property values than those based on transactions or liquidations, such as REIT return indexes.

An alternative view is that indexes of REIT returns are true returns on real estate if the market for REIT shares is efficient. Inefficiencies (i.e., REIT share prices not reflecting the values of the underlying real estate-related assets) are exploited through stock market trading, individual asset sales, and liquidation. Ennis and Burik (1991) cite several studies reviewed below (Allen and Sirmans, 1987, Shilling, Do, and Sirmans, 1989; Gyourko and Keim, 1992; Giliberto, 1989; and Chan, Hendershott, and Sanders, 1990) to support the notion that REIT shares are efficiently priced. A market efficiency argument, together with their claim that the observed volatility of REIT returns is consistent with generally accepted expectations about volatility in the true real estate return series, lead Ennis and Burik to select REIT return indexes over appraisal-based return indexes as proxies for the true returns on real estate.

One approach to resolving this controversy is to find evidence of market segmentation across return series for REITs, stock, and unsecuritized real estate. ${ }^{10}$ Ambrose, Ancel, and Griffiths (1992) test for segmentation among REITs and stocks during 1962 through 1989 using methods of fractal geometry. They conclude that both return series follow random walks that suggest no segmentation. Further, they conclude that REIT returns may not be good proxies for real estate returns. Liu, Hartzell, Greig, and Grissom (1990) find that equity REITs are integrated with the stock market, but they are unable to discern whether real estate is integrated with or segmented from the stock market (an important issue discussed in the pages to follow). ${ }^{11}$

Mengden and Hartzell (1986) in a Salomon Brothers report, develop and test a "hybrid securities" hypothesis about REITs. Their idea is that REITs exhibit market return characteristics associated both with the unsecuritized real estate market and the stock market, and that the two major components of REIT returns-dividends and price changes-are 
associated with incomes from real estate and stock prices, respectively. A statistical analysis confirms the hybrid securities hypotheses, but they conclude that REITs are not good substitutes for unsecuritized real estate in investor portfolios.

A stream of research on the composition of REIT returns follows from the Mengdon and Hartzell study. Corgel and Rogers (1991), for example, test the stock market and hybrid securities market hypotheses using returns data for individual REITs. They find that returns for some REITs correlate strongly to stock market returns, some REITs have hybrid securities characteristics, and returns for other REITs correlate with a proxy for real estate returns. Although results using firm-level data may have some appeal, research by Giliberto (1990, 1993), Gyourko and Keim (1992), Liu and Mei (1992), and Geltner (1990, 1992) provides the foundation for our understanding of the relationships between REITs, real estate, and stocks.

In Giliberto's 1990 paper, returns data for real estate (Russell-NCREIF), REITs (NAREIT equity trusts), stocks (S\&P 500), and bonds (Salomon Brothers Investment Grade Index) during 1978 through 1989 are analyzed in regressions that incorporate lagged relationships. Although Giliberto does not correct for smoothing in the Russell-NCREIF series, the analysis produces two important findings that have been confirmed in subsequent studies that use desmoothed, appraisal-based real estate series. First, correlations of the residuals from REIT and unsecuritized real estate return regressions indicate that a common factor (or factors) is present in both sets of returns. The common factor(s) is labeled "pure" real estate in the sense that it represents real estate market fundamentals. Second, lagged values of the equity REIT residuals explain variation in current period residuals from the RussellNCREIF return regression.

Giliberto (1993) extends his earlier findings with similar statistical technology to generate a "hedged" REIT index that directly relates the returns from securitized and unsecuritized real estate markets. Regressions run by Goetzman and Ibbotson (1990), using lagged values of levels of returns for securitized and unsecuritized real estate, produce little evidence that securitized markets contain useful information for predicting unsecuritized market returns. Using a more rigorous methodology (i.e., Granger casualty tests) than Giliberto (1990, 1993) and Goetzman and Ibbotson (1990), Myer and Webb (1993a) confirm that REIT returns lead, in an autocorrelative sense, to unadjusted, unsecuritized real estate returns.

The predictability of unsecuritized real estate returns using lagged REIT returns is confirmed by Gyourko and Keim (1992) who control for appraisal-induced persistence (i.e., smoothing) in the Russell-NCREIF return series. Stock market activity, specifically REIT trading, is shown to be an important source of information about changing real estate market fundamentals that later are reflected in appraisal-based indexes. Interestingly, Han (1991) turns the analysis in the opposite direction and concludes that previous appraisal-based smoothed returns influence in a statistically significant way the returns on REITs, thus bringing into question the efficiency of the REIT market.

Two additional findings from the Gyourko and Keim (1992) study deserve mention. First, REIT returns are found to be highly correlated with contemporaneous home appreciation rates from the existing homes price series of the National Association of Realtors, a result that provides evidence of a fundamental link between the transaction-based, securitized income property market and unsecuritized housing market. Second, major differences are found in the betas of real estate firms that perform dissimilar services (e.g., REITs that control property and construction companies), although no comparisons are drawn between individual REITs. 
A different approach to the question of leads and lags in real estate market data is adopted by Liu and Mei (1992a). Instead of concentrating on the predictability of appraisal-based returns using REIT data, REIT excess returns are decomposed to determine if there are expected excess returns that may be predicted using real estate capitalization rates. They find that expected excess returns on REITs are more predictable than expected excess returns for other securities. The larger predictable component of REIT excess returns leads to the conclusion that capitalization rates contain useful information about securitized returns on real estate. The analysis also leads to the conclusion that REITs are hybrid securities because of their strong statistical relationship with small capitalization stocks as well as their relationship with real estate capitalization rates. Myer and Webb (1993b), however, find no relationship between unsecuritized retail real estate and either retail REITs or retail stocks, as expected.

Several of the papers reviewed so far identify a common factor in unsecuritized and securitized real estate market returns. ${ }^{12}$ The final set of papers reviewed in this subsection present evidence about the presence of real estate market fundamentals in REIT return series. Such evidence is central for determining whether REITs are real, financial, or hybrid assets.

Geltner $(1990,1992)$ compares unsecuritized returns on real estate, measured by desmoothed Russell-NCREIF and Evaluation Associates indexes, to securitized returns on real estate, measured by unlevered NAREIT indexes. His 1990 paper addresses two questions regarding noise in unsecuritized and securitized real estate markets. Noise is defined as the excess volatility component of market return that is not based on information about future dividends and expected returns (i.e., the fundamentals). In response to the first question-are unsecuritized markets as noisy as securitized markets?-he concludes that the two markets are probably equally noisy. However, the two markets are not subject to the same, contemporaneous noise (i.e., the second question). In the final analysis, the fundamentals underlying the two markets appear to be more highly correlated than the endemic noise components, which is especially prevalent in the securitized market.

The 1992 Geltner paper involves detailed adjustments to the unsecuritized and securitized market return series and a more general comparative analysis of returns than the noisespecific comparison in Geltner (1990). Again, statistical similarities and differences among returns series from unsecuritized and securitized markets are found. Fundamental linkages are discovered in returns from the two markets over the long run even though the contemporaneous correlations of annual returns are low. Thus, Geltner's work confirms that longrun REIT returns are the same as desmoothed unsecuritized market returns, yet at discrete points, they are quite different.

In Barkham and Geltner (1993), evidence is presented that price changes in unsecuritized real estate follow price changes in securitized markets by a year or more. This result confirms the fundamentals link reported earlier in Geltner (1992), and suggests that REIT price movements may serve as predictors of property price changes. This result is contradictory to the findings of Liu and Mei (1992a) who conclude that capitalization rates contain useful information about securitized returns. Because price discovery is found to be more rapid and complete in Great Britain where the types and locations of securitized and unsecuritized properties are more similar than in the United States, further specialization of REITs from recent IPOs may lead to more rapid and complete transmission of information between United States securitized and unsecuritized real estate markets in the future.

Direct tests of the relationship between REIT returns and market fundamentals are conducted by Scott (1990) and Liu and Mei (1992b). Scott, using a database consisting of thirteen equity, mortgage, and hybrid REITs traded from the late 1960s through 1985, 
conducts regression and mean tests to determine if REIT prices track ex-post market fundamentals. He finds that REIT prices deviate from market fundamentals to such an extent that REIT prices are not reliable indicators of fundamental values. Liu and Mei (1992b) decompose the variance of REIT returns using a present value model, which allows the expected discount rate to vary through time in conjunction with a vector autoregressive procedure. The data are from 25 to 35 equity REITs traded during 1971-1989. Total risk is decomposed into expected and unexpected components, the latter accounting for most of the variation. Further decomposition of the unexpected return variance reveals that cash flow risk is the dominant factor. This evidence is considered validation of the important role of fundamental real estate analysis based on discounting cash flows.

Are REITs real estate or stocks? The evidence suggests the following:

- REIT returns lag real estate capitalization rates lead to coincide with some transaction based return series, and lead desmoothed, appraisal-based returns.

- REIT returns and returns from unsecuritized markets share a strong common component(s) that reflects real estate fundamentals.

- REIT returns are noisy and the noise is different than that found in other real estate return series.

In addition, the hybrid securities hypothesis appears to hold. The nominal returns on REITs are not real estate, but embedded in nominal REIT returns are the true returns on real estate.

\subsection{Asset acquisition and disposition}

Because they are public companies that invest extensively in real estate and mortgages, REITs are logical instruments with which to study real estate and mortgage acquisition and divestitute decisions. Yet surprisingly, few studies appear in print that either examine the machinery of REIT investment decision making or report on the consequences of asset changes from an ex-post shareholder wealth perspective.

A series of investor surveys dating from the 1970s to the mid-1980s reveal a pattern of increasing sophistication among real estate investors. Surveys by Farragher (1982) and Page (1983) use mixed samples of real estate investor types including REITs, corporations, life insurance companies, and other organizational forms. Comparisons across investor types indicate that REITs have been relatively slow to adopt modern investment analysis techniques. This general finding is confirmed by Webb and McIntosh (1986) in a survey of the investment behavior of 51 REITs. At that time, for example, most REITs made no systematic attempt to diversify their holdings. Unfortunately, the descriptive results from this stream of research tends to be period-specific and no follow-up studies have been conducted since the mid-1980s. Moreover, no experimental financial economics research has been performed to investigate the underlying behavioral parameters of REIT investment decision making. ${ }^{13}$

Investment decisions by REIT management, regardless of what analysis techniques are introduced, ultimately are judged by market responses to asset acquisitions and dispositions. Shilling, Sirmans, and Wansley (1986) indirectly test the hypothesis that REIT shares trade at discounts to net asset values by directly testing the hypothesis that announcements of property acquisitions have negative effects on share prices. They find no significant effects using price data before and after 33 acquisitions announcements by REITs from 1970 
through 1983. The same findings are reported in Glascock, Davidson, and Sirmans (1989) from a sample of 70 real estate acquisition announcements by primarily non-real estate firms. However, Glascock, Davidson, and Sirmans (1991) also find significant positive returns from a sample of only 30 single purchase corporate transactions. Motivated by the idea that these acquisition effects were driven by tax transfers, McIntosh, Ott, and Liang (1993) isolate tax-exempt transactions using REIT acquisition announcements. As in Shilling, Sirmans, and Wansley (1986), no significant excess returns resulted from REIT acquisitions.

McIntosh, Ott, and Liang (1993) instead find significant positive excess returns upon the announcements of REIT asset sales. ${ }^{14}$ These results are consistent with the finding from an event study by Elayan and Maris (1991) who examine share price responses for real estate firms (14 of 36 firms are REITs) that announce voluntary liquidation and reorganization. They report positive price movements surrounding announcements of liquidations and negative reponses to announcements of reorganizations. In the specific instance of an isolated REIT bankruptcy, the January 10, 1989, announcement of the bankruptcy of Residential Resources, a highly leveraged REIT that invested in CMO residuals, resulted in a significant event day decline of shares prices for REITs with similar portfolios (Asness and Smirlock 1991). Dissimilar REITs were unaffected.

For whatever reason, shareholder wealth is enhanced when REITs trim or liquidate their assets, but the market is unimpressed with REIT acquisition decisions and reorganizations.

\subsection{Corporate restructuring}

Property-level transactions may be considered special cases of corporate restructuring that involve entire REITs and units thereof. Lentz and Stern (1991) provide a detailed discussion of the rationale for using the REIT organizational form to restructure corporations. Also, they develop an NPV-based model that incorporates the tax advantages of forming REITs to restructure corporate real estate, although no direct evidence of shareholder wealth effects from such restructuring is presented in the article.

Only a few studies examine REIT share price responses to mergers and real estate unit restructuring. Allen and Sirmans (1987) consider the effects of REIT mergers on the wealth of the acquiring REIT shareholders. This study of 52 mergers from 1977 through 1983 is restricted to mergers in which both acquiring firms and target firms are REITs to allow for comparisons of the wealth effects of real estate firm mergers and general corporate mergers. They find that mergers provide statistically significant wealth increases for the acquiring REIT shareholders. This result contrasts with studies of non-REIT corporate mergers which find that the acquiring firm owners usually experience losses. Allen and Sirmans posit that improved asset management is source of the gain. Justification for this argument is based on evidence that mergers uniting like-kind REITs (i.e., REITs with similar portfolios of assets) create greater wealth gains to acquiring REIT shareholders than do other REIT mergers.

The specific effects of mergers on the wealth of target REIT shareholders are reported by McIntosh, Officer, and Born (1989). Their sample is not restricted to mergers in which both the acquiring and target firms are REITs. The data analysis indicates that target REITs experience statistically significant positive wealth effects from mergers. This result corresponds to the results found for target firms involved in general corporate mergers.

Finally, Rutherford, and Nourse (1988) present evidence that shareholder wealth is enhanced when firms create and restructure organizational units to purchase, develop, manage, 
and divest of real estate. Of the 71 events included in the sample, 19 involved the formation of REITs. Although Rutherford and Nourse conclude that the formation of REITs produces a one percent gain on the day prior to the announcement, the overall event-period shareholder wealth effects are somewhat mixed.

The existing REIT literature contains little evidence of the wealth effects from creating REITs to spin off and carve out real estate from corporation asset bases. Future empirical studies that attempt to fill this void should examine alternative types of REIT formations under a variety of real estate market conditions.

\subsection{Information: Good news/bad news}

Companies whose primary business is real estate hire professional appraisers to estimate the current values of their property holdings. This practice began in the late 1970s, but is generally not followed by non-real estate corporations. ${ }^{15} \mathrm{Gau}$ and Wang (1991) analyze share prices of real estate firms on the days surrounding current value announcements to measure the impact of this information on the market's valuation of the companies. Current value announcements are defined as statements appearing in the management overview section of $10-\mathrm{K}$ or incorporated annual reports that given estimates of the total appraised values of firms' properties as of specific dates. Sixty-one such announcements by REITs are analyzed along with 51 announcements by operating real estate companies. A cumulative abnormal return of $1.65 \%$ (positive and significant at the .05 level) is found for the sample thus indicating that REITs and operating real estate companies are undervalued by the stock market. The sample is not divided to specifically determine any undervaluation of REITs.

Appraisal information is creatively used by Damodaran and Liu (1993) to examine if insider trading activities of REIT and other real estate company shares are signals of private information to the stock market. Data are collected from Realty Stock Review on the dates that property appraisals were completed for 34 REITs and 20 other real estate companies from 1981 through 1988. These data are combined with insider trading information to examine the signalling effects of insider trading preceding the public announcement of the same property appraisal. Evidence is found to support the hypothesis that insiders increase (decrease) their holdings in response to good (bad) news about property values. Changes in insider holdings are found to act as signals eliciting correctly signed price responses, with the magnitudes of responses being correlated with the level of insider activity. Because of the advanced signals, no significant market reaction is found to public announcement of the same appraisal information. McIntosh and Zaman (1992) study the direct effect of insider trading on REIT share prices to find that insiders only earn abnormal returns when they buy shares. Surprisingly, the highest ranking officers in REITs earn abnormal returns similar to outside shareholders who trade large blocks of stock.

During recent years, much of the news about real estate values has been bad. Ghosh and Sirmans (1992) analyze stock price movements of REITs and other publicly traded real estate companies to determine the extent to which the market revalues these stocks in response to news of worsening real estate market conditions. They find that public announcements of real estate losses, especially realizations, induce significantly negative share price movements for stocks of banks, life insurance companies, and REITs. However, the effects are not as severe for REITs, which is attributed to the fact that REIT portfolios are more geographically diversified than portfolios of many financial institutions. 


\section{Review of the literature on financing issues}

The literature on REITs reviewed in this section address key topical areas of research in corporate finance. Included herein are studies of dividend policy to understand how REITs determine distributions to shareholders in light of highly restrictive qualification rules for tax-exempt status; literature that considers capital structure decisions for tax-exempt REITs as to the appropriate use of tax-sensitive debt and equity; studies adding to our understanding of the agency costs associated with REITs; literature on the initial public offerings of REIT shares; and papers devoted to extracting information from REIT trading data for capital budgeting purposes.

\subsection{Dividend policy}

The impact of dividend policy on the values of firms has been extensively studied in the corporate finance literature. In this respect, REITs are unique because their dividend policies are strongly influenced by the classification requirement that 95 percent of taxable income be distributed as dividends to avoid federal income taxes at the organization level. Lee and Kau (1987) argue that this requirement constrains the dividend policy of REITs relative to other corporations. Using monthly data from 29 REITs traded from 1971 through 1981, they confirm that REIT dividend payment decisions are constrained. Specifically, REIT earnings per share is not found to be an important variable for forecasting future dividends, thus contradicting the findings from previous studies of industrial firms. Also, Lee and Kau test for whether dividend policies affect the market values of REITs and find that high dividend payouts tend to increase shareholders' required rates of return, and therefore reduce the market values of REITs. It is hypothesized that this result is due to investor preferences for being taxed on capital gains rather than on dividends. ${ }^{16}$

In an unpublished paper by Shilling, Sirmans, and Wansley (1986), the information content of dividend change announcements by REITs is studied to capture the effects of dividend policy when management's ability to signal earnings expectations is constrained by tax rules. The analysis suggests that, even in the case of REITs in which management's ability to signal using dividends is limited and when dividends follow earnings, announcements of dividend increases convey significant positive information to investors.

Further support for the idea that REIT dividend payouts are less affected by qualification requirements than expected is offered by Wang, Erickson, and Gau (1992) who argue that the special tax status of REITs is not the sole determinant of dividend policy. They find that the 95 percent distribution requirement is not sufficient to fully explain REIT dividend policy because many REITs traded during the 1980s had dividend payout ratios well in excess of the qualification level. Data on 92 REITs from 1985 through 1988 show that REIT shareholders prefer high-dividend payout ratios. They theorize that high payout ratios insure further capital market monitoring of management investment decisions as REITs raise additional capital, thus agency costs due to imperfect market information are reduced. As in Shilling, Sirmans, and Wansley (1986), Wang, Erickson, and Gau (1992) find that dividends paid by equity REITs contain useful information. They argue that the potential exists for greater asymmetric information in dividend announcements from equity REITs than from mortgage REITs because of the nature of the underlying assets.

The existence of dividend clienteles among REIT investors is tested for by Maris and Elayan (1991). The data include marginal tax rates of investors in 94 REITs traded from 1982 through 1988 and divided into pre- and post-1986 Tax Reform Act subperiods. A 
statistically significant negative relationship is found between dividend yield and investor tax rates for mortgage and equity REITs during both subperiods which is consistent with the theory that high dividend paying firms attract investors with low marginal tax rates. However, results of tests for leverage clienteles are counter to theory, which states that taxpayers with high marginal tax rates prefer lowly leveraged investments.

Although some evidence exists to support the theory that REIT qualification rules on income payout distort dividend policy and convey useful signals to investors, there is not sufficient evidence to conclude that REITs are different than other firms with respect to the important dividend issues in corporate finance.

\subsection{Capital structure}

As tax-exempt, publicly traded companies, REITs offer unique opportunities for research that adds to the corporate finance literature on the relationship between taxes and the use of debt. REITs may use little or no debt because, as tax-exempt firms they must compete in the debt markets with firms for which interest expenses result in tax savings. Taxable firms therefore can afford to outbid tax-exempt firms, such as REITs, in debt markets. This logic led Howe and Shilling (1988) to hypothesize that REIT borrowings result in negative stock price reactions and equity offerings result in neutral market responses.

Howe and Shilling analyze 43 NYSE and AMEX REITs that reported stock or debt offering between 1970 and 1985 . Event study results show a strong positive reaction to debt announcements, which contrasts with the expected results. Because positive reactions to debt offerings occurred mostly with short-term debt announcements, it is hypothesized that this result is due to the reduction of uncertainty associated with continuing short-term borrowings through the development of improved banking relationships. Additionally, Howe and Shilling find significant negative reactions to equity offerings. This reaction is consistent with the notion that managers issue stock only when it is overpriced by the market.

Jaffee (1991) disputes the theoretical argument that debt offering announcements induce negative stock price reactions for tax-exempt firms, specifically REITs and traded partnerships. A model is offered to show that the values of REITs are invariant to the amount of leverage. Shareholders in REITs may garner tax deductions for interest through personal borrowing to buy shares, but when REITs borrow funds, shareholders receive no direct tax deductions for interest paid. The invariance result holds in Jaffe's model regardless of the competition for debt between taxpaying and non-taxpaying firms.

Cross-sectional regressions run by Maris and Elayan (1990) are used to estimate the relationship between various measures of leverage for REITs and firm-specific characteristics such as size, cash flow growth, and asset composition. Their hypotheses are that REITs, despite tax-exemptions, may be encouraged to borrow in the presence of agency costs and leverage clienteles. The use of debt is found to be higher for mortgage REITs (i.e., asset composition is significant and correctly signed), but only weak relationships are found for other endemic characteristics. The bimodally distributed capital structure of REITs supports the leverage clientele thesis, but no substantial support is found for an agency costs explanation for REIT leverage.

Even though Han (1991) concludes that the returns on REITs are the weighted average of the returns on the assets and debts of REITs (i.e., value additivity holds), knowledge may still be gained about the use of leverage from analyzing REIT experiences. Jaffe's (1991) article invites additional empirical work on capital structure with REIT data, particularly along the lines of Maris and Elayan (1990). 


\subsection{Agency costs}

As with industrial firms, agency costs arise with REITs due to conflicting interests between the parties managing the businesses and those supplying the capital. Alleviation of agency costs is achieved through incentive alignment contracting, such as compensation provisions for management based on financial performance. In 1978, more than one half of the REITs surveyed by Jankins (1980) used some form of incentive compensation. Yet he argues that conflicts of interest remain because incentives fees make leverage and asset risk taking more advantageous to the managers and advisors earning the fees than to shareholders. A recent survey by Golz (1993) of 16 large REITs finds that all compensate their CEOs with incentive compensation. Cash compensation however is the dominant component of total compensation.

Nevertheless, the important test of incentive provisions is overall financial performance. Using data for 38 REITs during 1972 through 1981, Solt and Miller (1985) find a positive relationship between incentive fees and financial performance in regressions explaining standard accounting ratios. Thus, the increasing fee structures they observe over time are consistent with the best interests of shareholders. In a slightly different study, Howe and Shilling (1990) are interested in the effect of advisor selection on REIT financial performance. Advisors to all publicly traded REITs during 1973 through 1987 are classified into the following seven categories: syndicators, real estate advisors, mortgage bankers, insurance companies, individuals, and others (not known). All categories of advisors are associated with either negative or zero abnormal returns to shareholders, with mortgage bankers producing the greatest negative result. They conclude that advisor selection has an important influence on returns from REIT investments.

Two specific agency hypotheses are tested with REIT data from 1980 through 1988 by Finnerty and Park (1991). The "window dressing" hypotheses states that managers who are compensated based on performance during calendar years will select undervalued, riskier assets during the earlier part of the year, and then later in the year if the strategy has been successful, they invest in safer assets to lock in portfolio returns. ${ }^{17}$ Excess returns are found to be higher in January than in other months for REITs managed on a calendar year and with incentive compensation arrangements. However, the differences between excess returns across the two groups are not statistically different, which leads to rejection of the window dressing hypotheses. ${ }^{18}$ Also, Finnerty and Park (1991) test the hypotheses that compensation arrangements based on performance influence the structure of organizatoin. They find that REITs that have performance incentive fees relative to other REITs are larger, pay higher dividends, and have greater leverage, more liquidity, more convertible debt, higher asset growth rates, and larger betas. ${ }^{19}$ Follow-up studies might focus on the question of whether incentive-based compensation promotes excessive risk taking (e.g., bankruptcy) or reduces total agency costs.

Some REITs, known as "captive-financing" affiliates and captive REITs, have business relationships with sponsors and advisors, thus creating agency relationships that may involve higher costs than for noncaptive REITs. Hsieh and Sirmans (1991) compare the performance during 1968 through 1986 of captive and noncaptive REITs. Captive REITs underperform noncaptive REITs and variables that typically explain financial performance are less significant for captive REITs. These results suggest that close business relationships between sponsors and advisors and REITs are associated with agency costs which affect financial performance. 
Agency problems also arise when managers try to protect themselves against hostile takeover attempts. McIntosh (1991) examines the stock price performance of 16 publicly traded REITs upon the announcement of antitakeover measures, such as poison pills. He finds a statistically significant decline in the stock price, thus providing evidence that management is acting in its own best interest as opposed to the interest of shareholders.

Finally, McIntosh, Rogers, Sirmans, and Liang (1992) examine the relationship between REIT stock market returns and top management changes. Their results indicate an inverse relationship between the probability of management changes and REIT share price performance, which indicates that internal monitoring of management by the board of directors, other top managers, and large block shareholders increases shareholder wealth via the reduction of agency costs. In addition, the results from this study support the hypotheses that information about management performance is reflected in the market returns.

\subsection{IPOs}

The initial public offering (IPO) underpricing anomaly is well documented in academic finance literature and in the financial press. However, underpricing has not been found for IPOs of securities such as closed-end mutual funds, master limited partnerships, and REITs, in which the underlying assets are easily identifiable and separately traded in security and asset markets. Two studies of REIT IPOs (Wang, Chan, and Gau, 1992; and Balogh and Corgel, 1992) find significant, albeit sometimes slight, overpricing. Wang, Chan, and Gau find that REIT overpricing is invariant to the offer price, issue size, distribution method, offer period, and underwriter reputation. They hypothesize that because REIT IPOs are primarily purchased by noninstitutional investors, overpricing may be due to informational problems.

Regressions run by Balogh and Corgel (1992) to explain the mispricing of REIT IPOs confirm that equity REITs are more likely to be mispriced than mortgage REIT IPOs. Their results support the theory that ownership retention by issuers is an important signal of efficient pricing, and also as expected, greater degrees of specification about REIT holdings presented in prospectuses along with historical information on property performance is associated with efficient pricing. However, involvement of prestigious auditors and investment bankers in REIT IPOs does not help explain mispricing.

One REIT IPO paper (Below, McIntosh, and Zaman, 1992) reports neither overpricing nor underpricing. Significant negative initial-day returns for mortgage REITs are found to be a function of using the bid prices to calculate returns for those securities which trade initially on the OTC. If either the bid-ask average or the ask prices are used to calculate returns, any apparent overpricing disappears. Additionally, they find that once transactions costs are considered, investors are better off purchasing REITs at the offering.

Despite some evidence of negative initial returns on REIT IPOs, short selling activity in newly formed REITs is negligible (Balogh, 1993). Future studies may reexamine this paradox and the two general questions about REIT IPOs. Are REIT IPOs overpriced or efficiently priced? Are there rational explanations for any mispricing, or is it the result of irrational behavior?

\subsection{Capital budgeting}

Because market data on unsecuritized real estate is notoriously scarce, REIT trading information has been considered a primary source of real estate rates of returns for capital 
budgeting purposes..$^{20}$ In some articles, rates are straight forwardly constructed from reported financial data for REITs (Gunterman and Smith, 1987). In other articles, combinations of weighted average cost of capital, capital asset pricing model, and other regression approaches are applied to REIT data to obtain rates for valuing properties and REITs (Wofford and Moses, 1978; Erickson and Freidman, 1987).

Cully and Shilling (1990) warn against using the dividend rates of REITs to proxy real estate equity dividend rates for valuing income-producing properties. Because REITs are subject to income, asset, and payout restrictions, adjustments are necessary to arrive at accurate estimates of equity dividend rates. They present a three-step procedure to adjust REIT rates of return for 1) capital gains, return of capital, and special dividends; 2) less than 100 percent payout; and 3) undistributed taxes on ordinary income.

Users of REIT data for property-level capital budgeting decisions may be unaware of the importance of the findings discussed earlier in subsection II-2. Adjustments recommended by Cully and Shilling (1990) may overcome translation problems associated with REIT qualification rules, but REIT returns are not true rates of return on real estate. Techniques for extracting the true rates of return on real estate from REIT returns are not available.

\section{Review of the literature on return and risk issues}

Financial economic theory stresses the need to diversify portfolios across different types of assets to obtain the optimal risk and return tradeoffs. This theory has stimulated researchers who are interested in real estate to think about whether the inclusion of real estate in mixedasset portfolios increases portfolio efficiency. Accordingly, a substantial number of papers have appeared that evaluate the financial performance of securitized real estate, the risk of holding securitized real estate, and the correlational relationships between securitized real estate returns and returns from other asset classes. The goal of this section is to review the literature specifically on REITs that addresses such issues. First, we review the literature on financial performance of REITs and the relationship between REIT performance and the performance of other asset classes such as stocks, bonds, and unsecuritized real estate. Next, we review the literature on the diversification gains from including REITs in mixed-asset portfolios. We complete this section by reviewing the literature on REIT investments to hedge against changes in the macroeconomic conditions, especially inflation.

\subsection{Financial performance: Returns}

The literature that tracks the financial performance of REITs and compares REIT and stock market returns may be characterized as diverse and confusing. Data are part of the problem. Glascock and Hughes (1992) discover only 12 firms for which data are available for the entire period dating from 1972 through 1990, and on average a REIT survives only for 94.6 months. Performance measurement is another problem. Glascock and Hughes report that on a nominal basis REITs underperformed the stock market from 1972 through 1990, but on a risk-adjusted basis REITs performed no better than the market. ${ }^{21}$ Titman and Warga (1986) analyze REIT performance using alternative risk-adjusted models to find that performance measures sometimes produce substantially different results. However, a comparison of the factor loading model and the macrovariable model by Chen, Hsieh, 
and Jordan (1993) produced different results using pre-1986 REIT data but the same results for the post-1986 period. Thus the selection of the period for performance measurement is a third concern. Lian, McIntosh, and Webb (1992) find that various REIT portfolios (i.e., all REITs, equity REITs, mortgage REITs, and hybrid REITs) experienced structural shifts in their return-generating processes. Significant switching points occurred in 1976, 1980, 1983, and 1986. A fourth potential problem of systematic coskewness is defeated by the finding from a study by Vines, Hsieh, and Hatern (1993) who are unable to find significant effects of skewness in nonadjusted REIT returns. Coskewness is shown to be an influential factor in explaining returns on unsecuritized real estate (Liu, Hartzell, and Grissom, 1992).

Probably because of a combination of the problems just mentioned, the literature on REIT returns represents vastly different conclusions about the relative performance of REITs. ${ }^{22}$ Smith and Shulman (1976), perhaps the first to seriously study REIT returns, find that equity REITs performed about the same as closed-end funds (i.e., portfolios of stocks) during 1963 through 1974. For long holding periods, Chan, Hendershott, and Sanders (1990), Han (1990), and Glascock (1991) find no excess returns using a variety of market model specifications. Yet, Hartzell and Mengden (1987) report four percent outperformance during 1972 through 1987, and Blake (1989) presents similar results during 1973 through 1980. Using REIT returns data from 1974 through 1991 in alternative APT models, Chen, Hsieh, and Jordan (1993) find abnormal returns only for the period 1980 through 1985.

Glascock (1991) also discovers no excess returns on REIT investments during short holding periods, including up-market periods, although most studies conclude that REITs either outperform or underperform the market during selected years. Such outcomes are documented in papers by Kuhle and Walther (1986), who report outperformance during 1973 through 1984; Kuhle, Walther, and Wurtzeback (1987) who report statistically significant outperformance during 1978 through 1985 and significant underperformance in 1974 and 1975; Blake (1989) who concludes that REITs outperformed the market during most of the 1970s through 1980s business cycle except the mid-1970s, with the greatest risk-adjusted returns occurring during upswing periods; and Martin and Cook (1991) who find that closedend funds outperformed individual REITs during the 1980s and portfolios of REITs from 1986 through 1990, but underperformed portfolios of REITs from 1980 through 1985. One study focuses on the performance of finite-life REITs (FREITs) relative to REITs and the stock market (Goebel and Kim, 1989). Both FREITs and REITs underperformed the market and REITs outperformed FREITs during 1983-1987.

Some attention has been given to determining if trading anomalies associated with the stock market apply to REITs. For example, Colwell and Park (1990) test for seasonality in REIT returns. Using a sample of 28 equity REITs and 33 mortgage REITs listed on the NYSE and AMEX during 1964 through 1986, they find that the average REIT returns are higher in January than in any other month. The abnormally high return in Jaunary disappears for both large equity and large mortgage REITs. Thus, a seasonality-size effect exists with REITs, a conclusion also reached by Liu and Mei (1992a) who find that the January effect accounts for five percent of the excess returns per year for equity REITs. A similar study by McIntosh, Liang, and Tompkins (1991) tests for the existence of a smallfirm effect. They examine REIT returns over 1974-1988 and assign REITs to portfolios based upon their relative market values. The small REITs provide greater returns without greater risk. Not surprisingly, other studies (e.g., Gyourko and Keim, 1991 and Liu and Mei, 1992a) find that excess returns on REIT investments move very closely with small capitalization stocks. 
From a study of REIT market microstructure Wang, Erickson, Gau, and Chan (1992) present a counterintuitive finding about the relationship of REIT returns and market vigilance. Shares of REITs tend to have small turnover ratios, lower institutional investor participation, and a smaller following among security analysts compared to other stocks. Moreover, contrary to predictions from an equilibrium model, REITs that are followed more closely by security analysts perform better than other REITs. Tax regulations pertaining to investor holdings cited in Section 1 of this review and the irrational investor hypotheses are offered as possible explanations.

Finally, a study by Goebel and Ma (1992) is motivated, in part, by the perception that REITs trade at discounts from their net asset values. ${ }^{23} \mathrm{~A}$ cointegration analyses confirms that a long-term, equilibrium relationship exists between REIT returns and the underlying accounting fundamentals of REITs; specifically net asset values and growth rates in sales, earnings, dividends, book values, and cash flow. Also, they find that REITs trade at approximately 77 percent of net asset values. The results from this study suggest that fundamental analysis, such as the approach recommended by Kuhle and Moorehead (1988), is helpful for selecting long-run investments in REITs.

\subsection{Risk and diversification}

Since the 1970s, estimates have been generated of the standard deviations of REIT returns and correlation coefficients relating REITs returns to stock market returns $\left(\rho_{\mathrm{RS}}\right)$ and REIT returns to unsecuritized, appraisal-based returns $\left(\rho_{\mathrm{RU}}\right)$. For example, Ross and Zisler $(1987 \mathrm{a}, 1987 \mathrm{~b}, 1991)$ report that $\rho_{\mathrm{RS}}=.67$ and $\rho_{\mathrm{RU}}=.14$ using nominal returns during 1978 through 1985, Mengden and Hartzell (1986) find that $\rho_{\mathrm{RS}}=.75$ and $\rho_{\mathrm{RU}}=.29$ using quarterly nominal returns during 1977 through 1986, Ennis and Burik (1991) report that $\rho_{\mathrm{RS}}=.80$ and the correlation between REITs and foreign stocks in .72 using nominal returns during 1980 through 1989, and Gyourko and Keim (1991) discover that $\rho_{\mathrm{RS}}=.65$ and $\rho_{\mathrm{RU}}=.10$ using excess returns during 1978 through $1990 .{ }^{24}$ Coincidently, the standard deviations of REIT return indexes and those of stock return indexes are found to be nearly identical in these studies, while the standard deviation of REIT return indexes are substantially higher than those for unsecuritized real estate return indexes.

The volatility of REIT returns declined significantly during the $1980 \mathrm{~s}$, both on an absolute basis and relative to the S\&P 500 (Giliberto, 1989; Khoo, Hartzell, and Hoesli, 1993; Liang, McIntosh, and Webb, 1993). The $\rho_{\mathrm{RS}}$ was in the range of .6 to .7 early in the decade then declined to the range of .4 to .5 by the end of the decade. The correlation between returns on REITs and bonds increased from less than .2 in 1980 to about .6 in 1989. Yet, the risk components for mortgage REITs are found to have varied considerably more than those for equity REITs from the 1970s through the 1980s (Liang, McIntosh, and Webb, 1993). Shifts in the riskiness of REITs are assumed to have occurred because investors became more aware of the underlying real estate characteristics of REITs and suggest that REITs receive greater portfolio allocations than was warranted based on the studies reviewed below. Khoo, Hartzell, and Hoesli (1993) find that the reduction in the standard deviation of equity REIT returns through 1989 is due to the increasing number of analysts following REITs, and coincidently, greater trading volumes of REIT shares. Yet, an updated version of Giliberto's 1989 (Giliberto, 1991) indicates that the volatility of equity REITs is increasing during the 1990 s and that the correlation pattern has partially reversed. 
Ross and Zisler (1987a, 1987b, 1991) and Hartzell and Mengden (1987) also report that the betas for REITs are .76 and .67 , respectively. The beta inflated to 1.23 during the 1990s (Ennis and Burik, 1991), and the betas for individual REITs are often higher than those for indexes. Patel and Olsen (1984) specify a regression equation to explain variation in the systematic risk of REITs. They find that beta is significantly and positively correlated with leverage, business risk, and advisor fees. However, their samples of 32 REITs traded during 1976 through 1978 is fairly limited and the variables in the regression explain less than 50 percent of the variation in REIT betas. In Giliberto (1990), a regression is run with equity REIT returns on the left side and stock market and bond market returns along with a quarterly dummy on the right side. Stock and bond market returns explain nearly 60 percent of equity REIT return variability.

Despite high correlations with other securitized assets, numerous studies have been designed to quantify the diversification effects from including REITs in portfolios. One of the first studies of this type is Miles and McCue (1982) who examine returns on portfolios of specialized REITs to determine the importance of property type and geographic diversification in real estate portfolios. Thus study uses 16 REITs listed from 1972 through 1978 and demonstrates favorable property type, but not geographic diversification effects. In another study using REIT data from the 1970s, Burns and Epley (1982) conclude that mixedasset portfolios consisting of REITs and stock are mean-variance efficient relative to single asset portfolios of either REITs or stocks. Burns and Epley are contradicted by Kuhle (1987) who uses a sample of returns from 26 equity REITs, 16 mortgage REITs, and 42 common stocks traded during 1980 through 1985 to examine the effects of diversification for reducing portfolio risk. He finds that the overall performance of portfolios combining common stock and REITs is not significantly different from portfolios of common stocks.

Mean-variance optimizations using expected returns on REITs and other assets during the 1980s indicate allocations to real estate of 10 to 15 percent (Ennis and Burik, 1991). Giliberto (1993), after creating a hedged REIT index, finds an optimal allocation to real estate of 19 percent. These allocations are consistent with previous studies, but well in excess of historical pension fund allocations to real estate (e.g., three to five percent). Both papers describe the problems of applying REIT indexes, such as NAREIT index, for portfolio analysis. It is argued that REITs indexes are essentially indexes of small capitalization stocks, which include health care REITs (e.g. NAREIT), and are heavily weighted toward REITs that invest in retail properties (e.g., NAREIT).

Holding diversification effects constant, Bharati and Gupta (1992) build a predictive model to find optimal asset allocations for stocks, risk-free assets, and real estate, proxied by REITs. The active investment strategy based on the model predictions is then compared to a passive investment strategy. The regression model predicts REIT and stock returns based on 14 variables, for example, T-bill yields and spreads, bond yields, stock dividend and earning ratios, growth of industrial production, and real estate capitalization rates. The results from the fundamentals model are better than results from passive strategies, thus suggesting that superior performance may not be due to diversification alone.

Finally, Liu and Mei (1993) use REIT data together with data for U.S. stocks and securitized real estate and stocks from six other countries to study whether international real estate markets are integrated. They find integration across real estate markets and moderate to high correlation between real estate and stock returns in each country. Nevertheless, it is suggested that investors include real estate of various countries along with its stocks to form efficient portfolios with low to intermediate levels of risk. 


\subsection{Hedging}

The studies reviewed in this subsection are concerned with the relationship between REIT returns and macroeconomic activity, particularly expected and unexpected inflation. The objective of this research is to determine the inflation hedging capabilities of REITs. Do REITs possess the inflation hedging characteristics commonly associated with real estate or are REIT returns negatively correlated with inflation, as are the returns on most financial assets?

Conceptually, the answer to these questions follows from the question of whether REITs are real estate or stocks. If REITs are hybrid securities, then their hedging potential may be limited. If the true real estate component in REIT returns is dominant, then investment in REITs may hedge inflation. But negative interest rate movements due to declining expected inflation that result in increases in the values of REIT assets also may result in higher REIT liabilities thus leaving the equity value unchanged (Titman and Warga, 1986). The empirical evidence presented below on REIT investments as inflation hedges indicates little support for the strategy.

Gyourko and Linneman (1988) examine the return series for the various categories of REITs using data from 1973 through 1986 and they find that REIT returns are strongly negatively correlated with inflation. This result is contrasted with the authors' examination of appraisal based real estate indices which indicates a positive relationship with inflation. Murphy and Klieman (1989), who measure the monthly returns on the NAREIT series during 1972 through 1985 , also find a statistically significant negative relationship between REIT returns and both expected and unexpected inflation. A similar study by Park, Mullineaux, and Chew (1990) uses the NAREIT index over nearly the same period and two proxies for expected inflation; T-bills and a survey-based measure. This study provides further evidence that REITs behave similarly to stocks in that they do not hedge against expected or unexpected inflation regardless of how inflation expectations are measured.

The findings from these inflation-specific studies are generally consistent with findings from some papers mentioned earlier that examine inflation effects in conjunction with REIT financial performance. Both Chan, Hendershott, and Sanders (1990) and Liu and Mei (1992a), for example, find that the long-term relationships are the same between REIT returns and inflation and stock market returns and inflation. Both REIT indexes and stock indexes are significantly positively related to changes in inflation during the 1980s, but unrelated (i.e., negative and insignificant) during the 1970s. Thus not surprisingly, a regression analysis by Goebel and Kim (1989) and an event study of CPI announcement effects by Myer and Webb (1990), which use data from the 1980s yield evidence of the inflation hedging capabilities of REIT investment.

A related paper by Chen and Tzang (1988) addresses the issue of whether REITs are sensitive to changes in short-term and long-term interest rates. The study includes both equity and mortgage REITs traded during 1973 through 1985 . Their results show that both equity and mortgage REITs are sensitive to changes in the long-term interest rates during 1973 through 1979. From 1980 through 1985, both equity REITs and mortgage REITs were sensitive to short term and long-term interest rates. Yet, Mengden (1988) argues that mortgage REITs may be more directly related to movements in the interest rate because mortgage REITs have a higher effective duration relative to equity REITs given that the underlying leases readjust to market conditions for properties held by equity REITs. Correlational evidence is provided that mortgage REITs are more sensitive to short-term interest rate changes than are equity REITs. Further confirmation that a large part of the market 
risk for mortgage REITs is derived from interest rate uncertainties comes from a study by Liang and Webb (1993). They find that interest rate risk is priced at equilibrium, which suggests the use of a two-factor market model for evaluating mortgage REIT performance (i.e., interest rate risk is not diversified).

The empirical relationship between monetary policy and real estate returns is examined by Darrat and Glascock (1989). Their sample consists of 31 firms including REITs, builders, and investment firms, and management companies during 1965 through 1986 . The results indicate that monetary policy measures have significant lagged relationships with current securitized real estate returns thus, market efficiency is questioned and the possibility exists to device trading rules based on past monetary policy data. Another study of macroeconomic effects by Sagalyn (1990) looks at the long-term performance of REITs relative to GNP growth (i.e., changes in the business cycle). Returns on REITs are higher, have lower volatility, and lower systematic risk during periods of high GNP growth. As in Gyourko and Keim (1990), both systematic risk and risk adjusted returns are far different over the business cycle for REITs than for real estate companies whose earning are tied to development and construction.

\section{Conclusions and future research}

The nearly one hundred papers included in this review and summarized in Table 2 at the end of this section share the common objective of advancing knowledge about the financial economics of real estate through the study of REITs. The early literature (i.e., 1970s to mid-1980s) concentrates on performance issues, such as return comparisons between REITs and stocks and portfolio studies to determine if REITs are diversifiers in mixed-asset portfolios. Curiosity about the role of REITs in institutional portfolios is mainly responsible for an avalanche of recent papers that carefully study the distributional parameters of REIT returns without reliance on the results from mean-variance optimization models. The evidence suggests that information on the fundamental drivers of true real estate returns travels between the property markets and securitized real estate markets, and ultimately resides in appraisal-based, unsecuritized real estate returns. Yet, there is uncertainty as to whether price discovery occurs in the property market or the securitized real estate market. More study of price information channels and the relationship between the return series, such as ongoing work by Fisher, Geltner, and Webb (1992), may help isolate the elusive common factor that constitutes the true return on real estate. In addition, price formation models following Quan and Quigley (1991) may be extended to provide an enhanced conceptual understanding of return generating processes.

Also, a common factor(s) associated with true returns on real estate may be shared in REIT and stock market returns. It is likely that soon this common factor will be isolated precisely so as to not only answer the question-are REITs stocks or real estate? but also to answer a more important question-how much of REIT returns are real estate returns? Once the extent to which REIT returns are real estate returns is known, REIT investment issues such as the wealth effects of asset acquisitions and dispositions, corporate restructurings, and new asset market information will be better understood.

As has been often noted, REITs offer unique opportunities to study longstanding issues in corporate finance because of the rules for maintaining tax-exempt status which govern REIT management behavior. While much has been learned about dividend policy, capital structure, and agency problems, gaps in the literature remain. Interrelationships among 
outcomes from REIT management decisions in a constrained world are not well understood. More theoretical work, such as Jaffe (1991), that examines the institutional characteristics of REITs is needed to guide future empirical studies. Finally, trading anomalies such as IPO overpricing, January effect, small-firm effect, and market microstructure have not been investigated to the fullest.

Table 2. Summary of the REIT literature.

2. LITERATURE ON INVESTMENT ISSUES

2.1. Are REITs Real Estate or Stocks?

\begin{tabular}{lll}
\hline \multicolumn{1}{c}{ Author(s) } & \multicolumn{1}{c}{ Sample } & \multicolumn{1}{c}{ Major Finding(s) } \\
\hline $\begin{array}{l}\text { Ross and Zisler } \\
(1987 \mathrm{a}, \text { 1987b, 1991) }\end{array}$ & 33 REITs, 1978-1985. & $\begin{array}{l}\text { Volatility of REITs prices overstates real estate } \\
\text { risk. True real estate returns are between REIT } \\
\text { and appraisal-based returns. }\end{array}$ \\
$\begin{array}{ll}\text { Goetzrnan and Ibbotson } \\
(1990)\end{array}$ & $\begin{array}{l}\text { Actively traded REITs, } \\
1972-1987 .\end{array}$ & $\begin{array}{l}\text { Appraisal-based indexes closer to true return, } \\
\text { REIT index too volatile, REITs cannot predict } \\
\text { unsecuritized real estate returns. }\end{array}$
\end{tabular}

Ennis and Burik (1991) NAREIT index, 1980-1989.

REIT index volatility consistent with true real estate volatility REITs are efficiently priced real estate.

Ambrose, Ancel, and Griffiths (1992)

Liu, Hartzell, Greig, and Grissom (1990)

Mengden and Hartzell (1986)

Corgel and Rogers (1991)

Giliberto (1990)

Giliberto (1993)

Myer and Webb (1993a)

Gyourko and Keim (1992)

Han (1991)

Liu and Mei (1992a)

Myer and Webb (1993b)

Geltner (1990)
Traded REITs, 1978-1986.

Traded REITs, 1978-1986.

19 equity REITs, 1977-1986.

52 REITs, 1981-1986.

Equity REITs, 1987-1989.

NAREIT index, 1978-3Q1991.

50 Equity REITs. 1978-1990.

Traded REITs (15-47), 1978-1990.

15 Survivor REITs, 1970-1989.

Equity REITs, 1971-1989.

8-10 retail REITs, 1983-1991.

NAREIT index, 1978-1989.
Stock market and REIT returns follow random walks, thus no segmentation. REITs returns not good proxies for real estate returns.

Stock market and REITs are integrated. No evidence of real estate integration with stock market.

REITs are hybrid securities.

Evidence that REITs are hybrid securities. Aggregation bias in indexes.

Significant common factor in REIT and unsecuritized real estate returns.

Hedged index brings together REIT and stock market common factor.

REIT Granger cause unadjusted appraisal-based returns.

REIT returns lead appraisal-based returns after controlling for smoothing.

REIT returns lag unadjusted appraisal-based returns.

Capitalization rates from real estate transaction contain useful information about securitized returns. REITs are hybrid securities.

Contemporaneous relationship between retail stocks and retail REITs but no relationships between either unsecuritized retail real estate and retail REITs or retail stocks.

Unsecuritized and securitized real estate markets equally noisy. Not the same noise. Fundamental components of returns more correlated than noise. 
Table 2. Summary of the REIT literature.

2.1. Are REITs Real Estate or Stocks? (cont.)

\begin{tabular}{|c|c|c|}
\hline Author(s) & Sample & Major Finding(s) \\
\hline Geltner (1992) & NAREIT index, 1974-1991. & $\begin{array}{l}\text { Fundamentals of securitized and unsecuritized } \\
\text { real estate markets linked over long run. }\end{array}$ \\
\hline $\begin{array}{l}\text { Barkham and Geltner } \\
\text { (1993) }\end{array}$ & NAREIT index, 1974-1992. & $\begin{array}{l}\text { Priced discovery occurs in securitized markets. } \\
\text { Information transmits to unsecuritized market in } \\
\text { a year or more. Transmission is quicker and } \\
\text { more complete in Britain. }\end{array}$ \\
\hline Scott (1990) & 13 REITs, late $1960 s-1985$. & $\begin{array}{l}\text { REIT prices are not reliable indicators of funda- } \\
\text { mental values. }\end{array}$ \\
\hline Liu and Mei (1992b) & $\begin{array}{l}25-35 \text { REITs, } \\
1971-1989.85\end{array}$ & $\begin{array}{l}\text { REIT variance related to cash flow risk, REIT } \\
\text { returns fundamentally linked to real estate cash } \\
\text { flows. }\end{array}$ \\
\hline
\end{tabular}

2.2. Asset Acquisition and Disposition

\begin{tabular}{|c|c|c|}
\hline Author(s) & Sample & Major Finding(s) \\
\hline Farragher (1982) & Survey of 26 REITs, 1991. & $\begin{array}{l}\text { REITs relatively slow to adopt modern investment } \\
\text { analysis techniques. }\end{array}$ \\
\hline Page (1983) & Survey of 31 REITs, 1982. & $\begin{array}{l}\text { REITs relatively slow to adopt to modern invest- } \\
\text { ment analysis techniques. }\end{array}$ \\
\hline $\begin{array}{l}\text { Webb and McIntosh } \\
\text { (1986) }\end{array}$ & Survey of 51 REITs, 1985. & $\begin{array}{l}\text { REITs use unsophisticated risk analysis and risk } \\
\text { mangement approaches. }\end{array}$ \\
\hline $\begin{array}{l}\text { Shilling, Sirmans, and } \\
\text { Wansley (1986) }\end{array}$ & $\begin{array}{l}26 \text { REITs property acquisi- } \\
\text { tions, } 1970-1983 .\end{array}$ & $\begin{array}{l}\text { No significant wealth effects from property } \\
\text { acquisitions. }\end{array}$ \\
\hline $\begin{array}{l}\text { McIntosh, Ott, and } \\
\text { Liang (1993) }\end{array}$ & $\begin{array}{l}92 \text { REITs property acquisi- } \\
\text { tions, } 1968-1990 .\end{array}$ & $\begin{array}{l}\text { No significant wealth effects from property } \\
\text { acquisitions, significant wealth effects }(+) \text { from } \\
\text { property sales. }\end{array}$ \\
\hline $\begin{array}{l}\text { Elayan and Maris } \\
\text { (1991) }\end{array}$ & $\begin{array}{l}14 \text { REITs of } 36 \text { firms } \\
\text { announcing voluntary } \\
\text { liquidation and } \\
\text { reorganizations. }\end{array}$ & $\begin{array}{l}\text { Wealth effects surrounding liquidations }(+) \text { and } \\
\text { reorganizations }(-) \text {. }\end{array}$ \\
\hline $\begin{array}{l}\text { Asness and Smirlock } \\
\text { (1991) }\end{array}$ & $\begin{array}{l}35 \text { REITs event period sur- } \\
\text { rounding bankruptcy of } \\
\text { Residential Resources REIT. }\end{array}$ & $\begin{array}{l}\text { Wealth effects }(-) \text { on event day, especially } \\
\text { severe for similar REITs. }\end{array}$ \\
\hline
\end{tabular}

2.3. Corporate Restructurings

\begin{tabular}{|c|c|c|}
\hline Author(s) & Sample & Major Finding(s) \\
\hline Lentz and Stern (1991) & No empirical analysis. & $\begin{array}{l}\text { Rationale for use of REITs to restructure firms, } \\
\text { provide NPV model incorporating tax effects. }\end{array}$ \\
\hline $\begin{array}{l}\text { Allen and Sirmans } \\
\text { (1987) }\end{array}$ & $\begin{array}{l}52 \text { REIT mergers, } \\
1977-1983 .\end{array}$ & $\begin{array}{l}\text { Preannouncement and announcement day wealth } \\
\text { effect }(+) \text { for acquiring firm shareholders. }\end{array}$ \\
\hline $\begin{array}{l}\text { McIntosh, Officer, and } \\
\text { Born (1989) }\end{array}$ & $\begin{array}{l}27 \text { mergers, REIT targets, } \\
1962-1968 .\end{array}$ & $\begin{array}{l}\text { Announcement day wealth effects }(+) \text { for target } \\
\text { firm shareholders. }\end{array}$ \\
\hline $\begin{array}{l}\text { Rutherford and Nourse } \\
\text { (1988) }\end{array}$ & $\begin{array}{l}71 \text { corporate real estate unit } \\
\text { formations, } 19 \text { REITs. } \\
1963-1986 .\end{array}$ & $\begin{array}{l}\text { Formation of REIT produces wealth effects }(+) \\
\text { but results mixed. }\end{array}$ \\
\hline
\end{tabular}


Table 2. Summary of the REIT literature.

\begin{tabular}{lll}
\hline \multicolumn{1}{c}{ 2.4. Information: Good News-Bad News } \\
\hline \multicolumn{1}{c}{ Author(s) } & \multicolumn{1}{c}{ Sample } & \multicolumn{1}{c}{ Major Finding(s) } \\
\hline Gau and Wang (1991) & $\begin{array}{l}\text { 51 REIT current value } \\
\text { reporting announcements, } \\
\text { 1977-1988. }\end{array}$ & $\begin{array}{l}\text { Wealth effect (+) indicating that REITs are } \\
\text { undervalued. }\end{array}$ \\
& $\begin{array}{l}\text { 34 REIT property appraisal } \\
\text { announcements, 1981-1988. }\end{array}$ & $\begin{array}{l}\text { Insiders respond to appraisals, no event-day } \\
\text { wealth effects. }\end{array}$ \\
$\begin{array}{l}\text { Damodaran and Liu } \\
\text { (1993) }\end{array}$ & $\begin{array}{l}\text { Insider trading for 50 } \\
\text { REITs, 1975-1987. }\end{array}$ & $\begin{array}{l}\text { Insider wealth effect }(+) \text { only upon purchase of } \\
\text { shares. }\end{array}$ \\
$\begin{array}{ll}\text { (1992) } \\
\text { Ghosh and Sirmans } \\
\text { (1992) }\end{array}$ & $\begin{array}{l}\text { (real estate market news, } \\
\text { 1989 and 1990. }\end{array}$ & $\begin{array}{l}\text { Wealth effect }(-) \text { from announcements of nega- } \\
\text { severe as for other firms. }\end{array}$ \\
\hline
\end{tabular}

\section{LITERATURE ON FINANCE ISSUES \\ 3.1. Dividend Policy}

\begin{tabular}{|c|c|c|}
\hline Author(s) & Sample & Major Finding(s) \\
\hline Lee and Kay (1987) & 29 REITs, 1971-1981. & $\begin{array}{l}\text { Dividend payment restriction constrains and } \\
\text { lowers market value of REITs. }\end{array}$ \\
\hline $\begin{array}{l}\text { Shilling, Sirmans, and } \\
\text { Wansley (1986) }\end{array}$ & $\begin{array}{l}26 \text { REIT dividend announce- } \\
\text { ments, 1970-1983. }\end{array}$ & $\begin{array}{l}\text { Management is able to signal positive informa- } \\
\text { tion to shareholders with dividend announcements. }\end{array}$ \\
\hline $\begin{array}{l}\text { Wang, Erickson, and } \\
\text { Gau (1992) }\end{array}$ & $\begin{array}{l}92 \text { REIT dividend announce- } \\
\text { ments, 1981-1988. }\end{array}$ & Shareholders prefer high dividend payment ratios. \\
\hline Maris and Elayan (1991) & 94 REITs, 1982-1988. & $\begin{array}{l}\text { Negative relationship found between dividend } \\
\text { yield and investor tax rates. }\end{array}$ \\
\hline
\end{tabular}

3.2. Capital Structure

\begin{tabular}{lll}
\hline \multicolumn{1}{c}{ Author(s) } & \multicolumn{1}{c}{ Sample } & \multicolumn{1}{c}{ Major Finding(s) } \\
\hline $\begin{array}{l}\text { Howe and Shilling } \\
(1988)\end{array}$ & 43 REITs, 1970-1985. & $\begin{array}{l}\text { Strong wealth effect (+) to debt announcement: } \\
\text { negative reaction to equity announcements. } \\
\text { Jaffe (1991) }\end{array}$ \\
No empirical analysis. & $\begin{array}{l}\text { Model shows REIT values invariant to leverage, } \\
\text { shareholders use homemade leverage for tax } \\
\text { deductions. }\end{array}$ \\
Maris and Elayan (1990) & 61 REITs, 1981-1987. & $\begin{array}{l}\text { Leverage clientele effect supported. } \\
\text { Han (1991) }\end{array}$ \\
$\begin{array}{l}\text { 15 survivor REITs, } \\
1970-1989 .\end{array}$ & Principles of value additivity holds for REITs. \\
\hline
\end{tabular}

3.3. Agency Costs

\begin{tabular}{lll}
\hline \multicolumn{1}{c}{ Author(s) } & \multicolumn{1}{c}{ Sample } & \multicolumn{1}{c}{ Major Finding(s) } \\
\hline Jenkins (1980) & Survey of 85 REITs, 1978. & Over one half offer incentive fee compensation. \\
Golz (1993) & $\begin{array}{l}\text { Survey of 16 large REITs, } \\
\text { 1991. }\end{array}$ & $\begin{array}{l}\text { All REITs provide incentive pay to CEOs but } \\
\text { cash compensation dominates. }\end{array}$ \\
Solt and Miller (1985) & 38 REITs, 1972-1981. & $\begin{array}{l}\text { Accounting ratio regressions show positive rela- } \\
\text { tionship between financial performance and } \\
\text { incentive fees. }\end{array}$
\end{tabular}


Table 2. Summary of the REIT literature.

3.3 Agency Costs (cont.)

\begin{tabular}{lll}
\hline \multicolumn{1}{c}{ Author(s) } & \multicolumn{1}{c}{ Sample } & \multicolumn{1}{c}{ Major Finding(s) } \\
\hline $\begin{array}{l}\text { Howe and Shilling } \\
\text { (1990) }\end{array}$ & 105 REITs, 1973-1987. & $\begin{array}{l}\text { Some advisors adversely effect financial } \\
\text { performance. }\end{array}$ \\
$\begin{array}{l}\text { Finnnerty and Park } \\
\text { (1991) }\end{array}$ & $\begin{array}{l}\text { REITs in NAREIT survey, } \\
1980-1988 .\end{array}$ & $\begin{array}{l}\text { Reject “window dressing" hypotheses, incentive } \\
\text { fee compensation has several effects on REIT } \\
\text { organization structure and behavior. }\end{array}$ \\
$\begin{array}{l}\text { Hsieh and Sirmans } \\
\text { (1991) }\end{array}$ & 55 REITs, 1968-1986. & $\begin{array}{l}\text { Captive REITs underperform noncaptive REITs } \\
\text { due to agency costs of close business relationships. }\end{array}$ \\
$\begin{array}{l}\text { McIntosh (1991) } \\
\text { 16 REIT announcements of } \\
\text { anti-takeover measure, } \\
\text { 1985-1989. }\end{array}$ & $\begin{array}{l}\text { Significant wealth effects (-) surrounding annouce- } \\
\text { ment of anti-takeover measure. }\end{array}$ \\
$\begin{array}{l}\text { McIntosh, Rogers, } \\
\text { Sirmans, and Liang } \\
\text { (1992) }\end{array}$ & $\begin{array}{l}\text { 55EIT announcements of } \\
\text { management changes, } \\
\text { 1969-1990. }\end{array}$ & $\begin{array}{l}\text { Wealth effects (-) associated with high probability } \\
\text { of management changes indicating that internal } \\
\text { monitoring reduces agency costs. }\end{array}$ \\
\hline
\end{tabular}

3.4. IPOs

\begin{tabular}{|c|c|c|}
\hline Author(s) & Sample & Major Finding(s) \\
\hline $\begin{array}{l}\text { Wang, Chan, and Gau } \\
\text { (1992) }\end{array}$ & 87 REIT IPOs, 1971-1988. & $\begin{array}{l}\text { Significant overpricing due to informational } \\
\text { problems. }\end{array}$ \\
\hline $\begin{array}{l}\text { Below, McIntosh, and } \\
\text { Zaman (1992) }\end{array}$ & 58 REIT IPOs, 1972-1989. & $\begin{array}{l}\text { REIT IPOs are correctly priced in initial market. } \\
\text { Apparent overpricing disappears when ask prices } \\
\text { are used to calculate returns. }\end{array}$ \\
\hline $\begin{array}{l}\text { Balogh and Corgel } \\
\text { (1992) }\end{array}$ & 49 REIT IPOs, 1978-1989. & $\begin{array}{l}\text { Significant, but slight overpricing, equity REITs } \\
\text { more overpriced, ownership retention by issuers } \\
\text { important signal. }\end{array}$ \\
\hline Balogh (1993) & 22 REIT IPOs, 1980-1989. & $\begin{array}{l}\text { Despite negative initial returns on REIT IPOs, } \\
\text { short selling activity is negligible. }\end{array}$ \\
\hline \multicolumn{3}{|c|}{ 3.5. Capital Budgeting } \\
\hline Author(s) & Sample & Major Finding(s) \\
\hline $\begin{array}{l}\text { Gunterman and Smith } \\
\text { (1987) }\end{array}$ & 41 REITs, 1971-1982. & $\begin{array}{l}\text { Before- and after-tax cost of capital estimates } \\
\text { from REIT and other data for investment and } \\
\text { appraisal purposes. }\end{array}$ \\
\hline $\begin{array}{l}\text { Wofford and Moses } \\
\text { (1978) }\end{array}$ & 10 REITs, 1970s. & $\begin{array}{l}\text { Estimate equity rates from REIT data using } \\
\text { CAPM and other regression approaches. }\end{array}$ \\
\hline $\begin{array}{l}\text { Erickson and Fredman } \\
\text { (1987) }\end{array}$ & Selected REIT data, 1986 & $\begin{array}{l}\text { Develop cost of capital estimates for valuing } \\
\text { REITs using standard models in corporate finance. }\end{array}$ \\
\hline $\begin{array}{l}\text { Cully and Shilling } \\
\text { (1990) }\end{array}$ & 17 REITs, 1986-1987. & $\begin{array}{l}\text { Produce equity dividend rates from three-step } \\
\text { adjustment of REIT dividend yields. }\end{array}$ \\
\hline
\end{tabular}

4. LITERATURE ON RETURN, RISK, AND PORTFOLIO ISSUES

4.1. Financial Performance Returns

\begin{tabular}{lll}
\hline \multicolumn{1}{c}{ Author(s) } & \multicolumn{1}{c}{ Sample } & \multicolumn{1}{c}{ Major Finding(s) } \\
\hline $\begin{array}{l}\text { Glascock and Hughes } \\
\text { (1993) }\end{array}$ & 137 REITs 1972-1991. & $\begin{array}{l}\text { Performance studies hampered by survivorship } \\
\text { problems. Long-run, risk-adjusted returns below } \\
\text { the market. }\end{array}$
\end{tabular}


Table 2. Summary of the REIT literature.

4.1. Financial Performance Returns (cont.)

\begin{tabular}{lll}
\hline \multicolumn{1}{c}{ Author(s) } & \multicolumn{1}{c}{ Sample } & \multicolumn{1}{c}{ Major Finding(s) } \\
\hline $\begin{array}{l}\text { Titman and Warga } \\
\text { (1986) }\end{array}$ & 36 REITs, 1973. & $\begin{array}{l}\text { Due to volatility of REIT returns, CAPM and } \\
\text { APT models inadequate to evaluate performance } \\
\text { of individual REITs. }\end{array}$
\end{tabular}

Chen, Hsieh, and

Jordan (1993)

12-27 equity REITs, 1974-1991.

Liang, McIntosh, and Webb (1993)

Vines, Hsieh, and

Hatern (1993)

Smith and Shulman (1976)

Chan, Hendershott, and Sanders (1990)

Han (1990)

Glascock (1991)

Hartzell and Mengdon (1987)

Blake (1989)

Kuhle and Walther (1986)

Kuhle, Walther, and Wurtzebach (1986)

Martin and Cook (1991)

Goebel and Kim (1989)

Colwell and Park (1990)

Liu and Mei (1992a)

McIntosh, Liang, and Tompkins (1991)

Wang, Erickson, Gau, and Chan (1992)

33 (ave.) EREITs, 1971-1991.

16 equity REITs, 1963-1974.

30 equity REITs, 1973-1987. REITs, 1983-1987.
36-102 REITs, 1973-1989. Significant shifts in REIT return generating

21-100 REITs, 1970-1988.

109 REITs, 1965-1986.

NAREIT index, 1972-1987.

22 REITs, 1970-1988.

102 REITs, 1973-1984.

102 REITs, 1973-1985.

16-34 REITs, 1980-1990.

32 REITs and finite-life

61 REITs, 1964-1986.

Equity REITs, 1971-198 .

Traded REITs, 1974-1988.

134 REITs, 1970-1989. processes-1976, 1980, 1983, and 1986.

Alternative APT models produce different results prior to 1986 , but the same results after 1986. Abnormal returns for REITs only during 1980-1985.

Coskewness not present in REIT returns.

REITs and closed-end funds perform about the same.

REITs risk-adjusted returns same as stocks, less risky than stocks, and do not hedge unexpected inflation.

Performance of REIT and stock portfolios comparable, equity REITs outperform mortgage REITs, short-term relative performance varies.

No excess returns for REITs under various market conditions.

REITs outperform stock market by 4 percent long-term, short-term results vary.

REITs outperform stock market long term, higher risk-adjusted return during upswings, higher volatility during downswings.

REIT risk-adjusted returns significantly greater than zero.

REIT performance versus stock market mixed, some evidence that REITs are efficiently priced.

Individual REITs underperform closed-end funds, portfolios of REITs outperform closed-end funds.

Finite-life REITs underperform REITs and both underperform stock market, REITs do not hedge total and unanticipated inflation.

January effect confirmed, disappears with greater size.

January effect accounts for five percent of excess returns for equity REITs.

Small-firm effect confirmed.

REITs have unique market microstructure, performance positively related to number of analysts following REITs. 
Table 2. Summary of the REIT literature.

4.1. Financial Performance Returns (cont.)

\begin{tabular}{lll}
\hline \multicolumn{1}{c}{ Author(s) } & \multicolumn{1}{c}{ Sample } & \multicolumn{1}{c}{ Major Finding(s) } \\
\hline Goebel and Ma (1993) & Traded REITs, 1972-1992. & $\begin{array}{l}\text { Long-term equilibrium between REIT returns } \\
\text { and accounting fundamentals. REITs trade a dis- } \\
\text { count from net asset values. }\end{array}$ \\
$\begin{array}{l}\text { Kuhle and Moorehead } \\
(1988)\end{array}$ & 102 REITs, 1977-1985. & $\begin{array}{l}\text { Accounting fundamentals help select outperform- } \\
\text { ing REITs. }\end{array}$ \\
\hline
\end{tabular}

4.2. Risk and Diversification

\begin{tabular}{|c|c|c|}
\hline Author(s) & Sample & Major Finding(s) \\
\hline $\begin{array}{l}\text { Ross and Zisler } \\
(1987 \mathrm{a}, 1987 \mathrm{~b}, 1991)\end{array}$ & 33 REITs, 1978-1985. & $\begin{array}{l}\text { Correlation of REIT and stock market returns } \\
\left(\rho_{\mathrm{RS}}\right)=.67 \text {, correlation of REIT and unsecuri- } \\
\text { tized real estate market returns }\left(\rho_{\mathrm{RU}}\right)=.14 \text {, } \\
\beta=.76 \text {. }\end{array}$ \\
\hline $\begin{array}{l}\text { Mengden and Hartzell } \\
\text { (1986) }\end{array}$ & 19 equity REITs, 1977-1986. & $\rho_{\mathrm{RS}}=.75, \rho_{\mathrm{RU}}=.67$ \\
\hline Ennis and Bunk (1991) & NAREIT index, 1980-1989. & $\begin{array}{l}\rho_{\mathrm{RS}}=.80 \text { correlation of } \mathrm{REIT} \text { and foreign stock } \\
\text { returns }=.72, \beta=1.23,10-15 \text { percent alloca- } \\
\text { tions to real estate. }\end{array}$ \\
\hline $\begin{array}{l}\text { Gyourko and Keim } \\
\text { (1991) }\end{array}$ & $\begin{array}{l}\text { Traded REITs }(15-47) \text {, } \\
1978-1990 .\end{array}$ & $\rho_{\mathrm{RS}}=.65, \rho_{\mathrm{RU}}=.10$ \\
\hline Giliberto $(1989,1991)$ & NAREIT index, 1978-1990. & $\begin{array}{l}\text { Volatility of REITs declined during } 1980 \text { s in } \\
\text { absolute terms and relative to S\&P } 500 \text {, reversal } \\
\text { occurring during the 1990s. }\end{array}$ \\
\hline $\begin{array}{l}\text { Khoo, Hartzell, and } \\
\text { Hoesli (1993) }\end{array}$ & 14 equity REITs, 1970-1989. & $\begin{array}{l}\text { Reduction in REIT betas and return standard } \\
\text { deviations is due to the increasing number of } \\
\text { analysts following REITs, and coincidently, more } \\
\text { trading volume. }\end{array}$ \\
\hline $\begin{array}{l}\text { Lioan, McIntosh, and } \\
\text { Webb (1993) }\end{array}$ & 36-102 REITs, 1973-1989. & $\begin{array}{l}\text { Variability of risk components of mortgage REITs } \\
\text { greater than those of equity REITs during } 1970 \text { s } \\
\text { and 1980s. }\end{array}$ \\
\hline Patel and Olsen (1984) & 32 REITs, 1976-1978. & $\begin{array}{l}\text { Beta positively related to leverage, business risk, } \\
\text { and advisor fees. }\end{array}$ \\
\hline Giliberto (1990) & Equity REITs, 1978-1989. & $\begin{array}{l}\text { Stock and bond market returns explain } 60 \text { percent } \\
\text { of REIT returns variability. }\end{array}$ \\
\hline $\begin{array}{l}\text { Miles and McCue } \\
\text { (1982) }\end{array}$ & 18 REITs, 1972-1978. & $\begin{array}{l}\text { REIT portfolios used to show benefits from } \\
\text { property type diversification. }\end{array}$ \\
\hline Burns and Epply (1982) & 35 REITs, 1970-1979. & $\begin{array}{l}\text { Portfolios of REITs and stocks efficient relative } \\
\text { to either REIT or stock portfolios. }\end{array}$ \\
\hline Kuhle (1987) & $\begin{array}{l}42 \text { REITs of } 84 \text { firms, } \\
1980-1985 .\end{array}$ & $\begin{array}{l}\text { Portfolios of REITs and stocks perform same as } \\
\text { portfolios of stocks. }\end{array}$ \\
\hline Giliberto (1993) & $\begin{array}{l}\text { NAREIT index, } \\
\text { 1978-3Q1991. }\end{array}$ & $\begin{array}{l}\text { Using hedged index returns there is a } 19 \text { percent } \\
\text { allocation to real estate. }\end{array}$ \\
\hline $\begin{array}{l}\text { Bharati and Gupta } \\
\text { (1992) }\end{array}$ & 30 REITs, 1973-1990. & $\begin{array}{l}\text { Superior performance from active investment in } \\
\text { REITs results from analysis of fundamentals, not } \\
\text { necessarily diversification. }\end{array}$ \\
\hline
\end{tabular}


Table 2. Summary of the REIT literature.

4.2. Risk and Diversification

\begin{tabular}{cll}
\hline \multicolumn{1}{c}{ Author(s) } & \multicolumn{1}{c}{ Sample } & \multicolumn{1}{c}{ Major Finding(s) } \\
\hline Liu and Mei (1993) & NAREIT index, & International real estate markets are integrated. \\
& 1978-3Q1991. & $\begin{array}{l}\text { Yet efficient portfolios include stocks and securi- } \\
\text { tized real estate from various countries. }\end{array}$ \\
\hline
\end{tabular}

4.3. Hedging

\begin{tabular}{ccc}
\hline Author(s) & Sample & Major Finding(s) \\
\hline
\end{tabular}

\begin{tabular}{lll}
\hline $\begin{array}{l}\text { Gyourko and Linneman } \\
\text { (1988) }\end{array}$ & NAREIT index, 1972-1986. & $\begin{array}{l}\text { REIT returns have strong negative correlation } \\
\text { with inflation. }\end{array}$
\end{tabular}

Murphy and Klieman (1989)

NAREIT index, 1972-1985. REIT returns negatively correlated with expected and unexpected inflation. REITs do not effectively hedge inflation.

Park, Mullineaux, and Chew (1990)

Chan, Hendershott, and Sanders (1990)

Liu and Mei (1992a)

Goebel and Kim (1989)

Myer and Webb (1990)

Chen and Tzang (1988)

Mengden (1988)

Liang and Webb (1993) 61 REITs, 1976-1990.

Durrate and Glascock (1989)

Sagalyn (1990)
21 REITs, 1985-1989.

54 REITs, 1973-1985.

REITs among 31 real estate firms, 1965-1986.

NAREIT index, 1972-1986.

38 equity REITs, 1973-1987.

Equity REITs, 1971-1989.

NAREIT index, 1980-1987.

20 REITs, 1973-1989.
REITs, like stocks, generally found to be negatively correlated with anticipated inflation.

REIT inflation hedging ability poor, similar to stocks.

REIT inflation hedging, ability poor, similar to stocks.

Regression results from 1980s shows REITs hedge inflation.

CPI announcement effects indicate REITs hedged inflation during 1980s.

REITs sensitive to interest rate changes, especially long-term rates.

Mortgage REIT dividend yields more positively related to movements in interest rates than are yields on equity REITs.

Market risk of mortgage REITs is largely interest rate risk which is not diversified away. Thus, a two-factor market model should be used for performance evaluation.

Monetary policy measures have lagged relationship to current REIT returns.

During high GNP growth; REIT returns higher, volatility lower, and systematic risk lower.

\section{Notes}

1. Detailed histories and specific tax and accounting information are well documented elsewhere. Some examples are Lynn, Goldberg, and Steinfeld (1987), Haight and Ford (1987), Jarchow (1988), and Knight and Knight (1992).

2. An additional criterion that limited REIT share ownership, commonly referred to as the five-or-fewer rule, was virtually eliminated with the enactment of the Omnibus Budget Reconciliation Act of 1993. 
3. Equity, mortgage trusts, and hybrid are classified by NAREIT using the following rules:

- REITs are equity trusts if directly held real estate comprises a minimum of $75 \%$ of the trust's portfolios.

- REITs are mortgage trusts if mortgages constitute a minimum of $75 \%$ of the trusts' portfolios.

- REITs are hybrid trusts if directly held real estate comprises less than $75 \%$ and mortgages constitute less than $75 \%$ of the trusts' portfolios.

4. Health-care REITs are typically included in the equity REIT group and are known for purchasing properties and leasing them back to health-care providers. Industry analysts prefer to treat these REITs separately because the assets are not standard income producing property and are exposed to considerable non-real estate risks.

5. Some REITs have been formed as the result of corporate asset restructuring. See Lentz and Stern (1991).

6. Alex, Brown \& Sons (1993) reports that 1992 was a record year for raising capital using the REIT structure with $\$ 6.4$ billion in debt and equity capital raised. Over one-half billion dollars was raised during the last two weeks of 1992.

7. See Miles (1990) for a review of the evidence on estimating the total value of U.S. real estate.

8. See Quinn (1987).

9. Major findings from this study also appear in a 1991 issue of The Journal of Real Estate Finance and Economics (Ross and Zisler, 1991).

10. If investors do not earn the same expected return in two markets (e.g., REITs and stocks), then the markets are segmented (Liu, Hartzell, Greig, and Grissom, 1990).

11. Goebel and Kim (1989) hypothesize that finite-life REITs (FREITs), given their closed-end and transaction based structure, more closely track returns on the underlying real estate than REIT, in general. They find that FREIT returns are less correlated with the stock market returns than are REIT returns, thus providing indirect evidence that FREITs have the stronger real estate component.

12. Also, Eichholtz and Hartzell (1992) examine the relationships between returns of REITs (and similar firms), appraisal-based indexes, and the stock markets in several countries, including the United States. The results suggest strong relationships between securitized real estate markets, stock markets, and unsecuritized real estate markets. However, no attempt is made to determine leads and lags with regard to real estate fundamentals.

13. An example of an experimental financial economics paper on investment decision making is Forsythe, Palfrey, and Plott (1982).

14. Weak evidence of excess returns also is reported by Glascock, Davidson, and Wallace (1989) for non-real estate company asset dispositions.

15. Palmon and Seidler (1978) argue that corporate restructuring involving real estate are motivated by an inefficiency stemming from real estate being reported on balance sheets at historical costs rather than at market values.

16. During most of their study period the capital gains tax rate was 40 percent of the rate on ordinary (dividend) income.

17. The strategy is similar to the January effect strategy induced by tax related buying and subsequent selling.

18. Colwell and Park (1990) also provide evidence of the January effect in REIT trading, but the effect is only present in small and medium size equity and mortgage trusts.

19. The positive relationship between REIT betas and advisors fees also is demonstrated in regressions run by Patel and Olsen (1984).

20. This possibility was recognized as early as 1970 by Faulkner (1970).

21. An examination of Table 1 of this review reveals that since 1990 REITs have outperformed the S\&P 500 on a nominal basis. These data highlight the problem of time period selection for performance measurement.

22. Nominal returns on REITs are presented in Table 1 of this review. Also, some papers that are not discussed in this section present nominal returns that are consistent with those in Table 1 and excess returns are consistent with those reviewed herein (e.g., see Ross and Zisler, 1987a, 1987b, 1991 and Giliberto, et al., 1993).

23. Shilling, Sirmans, and Wansley (1986) are similarly motivated. See subsection 2.2 of this review.

24. Hartzell and Mengden (1987) show that $P_{R S}$ tends to be smallest when using monthly intervals for return calculations.

\section{References}

Alex, Brown \& Sons, Inc. (1993). Real Estate Stock Monitor, Research-Real Estate (February) Baltimore. Allen, Paul R. and Sirmans, C.F. (1987). "An Analysis of Gains to Acquiring Firm's Shareholder-The Special Case of REITs," Journal of Financial Economics, 18(1), 175-184.

Ambrose, Brent W., Ancel, Esther, and Griffiths, Mark D. (1992). "The Fractal Structure of Real Estate Investment Trust Returns: The Search for Evidence of Market Segmentation and Nonlinear Dependency," AREUEA Journal, 20(1), 25-54. 
Asness, Cliff, and Smirlock, Michael. (1991). "A Note on REIT Bankruptcy and Intraindustry Information Transfers: An Empirical Analysis," Journal of Banking and Finance, 15(6), 1171-1182.

Balogh, Colin. (1993). "Short Interest: The Case of REIT IPOs 1993," working paper, Bentley College.

Balogh, Colin, and Corgel, John B. (1992). "Initial Return Behavior of One Class of Composite Security IPOs: REITs," working paper, Bentley College.

Barkham, Richard, and Geltner, David. (1993). "Price Discovery and Efficiency in American and British Property Markets," working paper, University of Cincinnati.

Below, Scott, McIntosh, Willard, and Zaman, Mir A. (1992). "The Pricing of Real Estate Investment Trust Initial Price Offerings," working paper, University of Kentucky.

Bharati, Rakesh, and Gupta, Manoj. (1992). "Asset Allocation and Predictability of Real Estate Returns," The Journal of Real Estate Research, 7(4), 469-484.

Blake, Cameron S. (1989). "The Real Estate Investment Trust: Performance Over the Business Cycle," working paper, MIT.

Burns, William L., and Epley, Donald R. (1982). "The Performance of Portfolios of REITs and Stocks," Journal of Portfolio Management, 8(3), 37-42.

Chen, Su-Jane, and Hsich, Cheng-Ho. (1993). "The Comparison of Two Multi-Factor Models on the Application of REIT Returns," working paper, University of Wisconsin-Eau Claire.

Chen, K.C., and Tzang, Daniel D. (1988). "Interest-Rate Sensitivity of Real Estate Investment Trusts," The Journal of Real Estate Research, 3(3), 13-21.

Chan, K.C., Hendershott, Patric H., and Sanders, Anthony B. (1990). "Risk and Return on Real Estate: Evidence from Equity REITs," AREUEA Journal, 18(4), 431-452.

Colwell, Peter F., and Park, Hun Y. (1990). "Seasonality and Size Effects: The Case of Real-Estate Related Investment," Journal of Real Estate Finance and Economics, 3(3), 251-259.

Corgel, John B., and Rogers, Ronald C. (1991). "Market Trading Characteristics of REITs Tests of the Stock Market and Hybrid Securities Hypotheses," working paper, Cornell University.

Culley, Scott C., and Shilling, James D. (1990). "REIT Dividend Rates and Their Implications for Valuing IncomeProducing Real Estate," The Appraisal Journal, 58(3), 386-394.

Darrat, Ali F., and Glascock, John L. (1989). "Real Estate Returns, Money and Fiscal Deficits: Is the Real Estate Market Efficient?," Journal of Real Estate Finance and Economics, 2(3), 197-208.

Damodaran, Aswath, and Liu, Crocker H. (1993). "Insider Trading as a Signal of Private Information," Review of Financial Studies, 6(1), 79-119.

Eichholtz, Piet M.A., and Hartzell, David J. (1992). "Real Estate Investment Trusts, Appraisals, and the Stock Market: An International Perspective," working paper, University of North Carolina.

Elayan, Fayez A., and Maris, Brian A. (1991). "Stock Market Response to Voluntary Liquidations and Reorganizations of Real Estate Corporations," AREUEA Journal, 19(1), 92-101.

Ennis, Richard M., and Burik, Paul. (1991). "Pension Fund Real Estate Investment Under a Simple Equilibrium Pricing Model," Financial Analysts Journal, 47(3), 20-30.

Erickson, John R., and Fredman, Albert J. (1987). "Estimating the Cost of Capital for a REIT: A Case Study," The Real Estate Appraiser and Analyst, 53(1), 39-47.

Farragher, Edward J. (1982). "Investment Decision-Making Practices of Equity Investors in Real Estate," The Real Estate Appraiser and Analyst, 48(2), 36-40.

Faulkner, Phillip G. (1970). "REITs-Equity Returns in a Fish Bowl," The Appraisal Journal, 38(4), $485-494$.

Finnerty, Joseph E., and Park, Hun Y. (1991). "Managerial Compensation and the Characteristics of Firms. The Case of REITs," working paper, University of Illinois.

Fisher, Jeffrey D., Geltner, David, and Webb, R. Brian. (1992). "Historical Value Indices of Commercial Real Estate," working paper, Indiana University.

Forsythe, Robert, Palfrey, Thomas R., and Plott, Charles R. (1982). "Asset Valuation in an Experimental Market," Econometrica, 50(3), 537-567.

Gau, George W., and Wang, Ko (1991). "Current Value Reporting and the Stock Market Valuation of Real Estate Companies," working paper, University of Texas.

Geltner, David. (1990). "Real Estate and the Diversifiability of Stock Market Noise," working paper, University of Cincinnati.

Geltner, David. (1992). "Estimating Market Value from Appraised Values Without Assuming an Efficient Market," working paper, University of Cincinnati.

Ghosh, Chinmoy, and Sirmans, C.F. (1992). "Real Estate Lending and Reaction of Institutional Stock Prices to the Real Estate Crisis," working paper, University of Connecticut.

Giliberto, S. Michael. (1989). Equity Real Estate Investment Trusts and Portfolios Diversification, New York: Salomon Brothers, Inc. 
Giliberto, S. Michael. (1990). “Equity Real Estate Investment Trusts and Real Estate Returns, The Journal of Real Estate Research, 5(2), 259-263.

Giliberto, S. Michael. (1991). Equity Real Estate Investment Trust Capital Market Trends: An Update, New York: Salomon Brothers, Inc.

Giliberto, S. Michael. (1992). An Overview of Real Estate Investment Trusts, New York: Salomon Brothers, Inc.

Giliberto, S. Michael. (1993). "Measuring Real Estate Returns: The Hedged REIT Index," The Journal of Portfolio Management, 19(3), 94-99.

Giliberto, S. Michael, Lydon, Bedford H., Byrne, Therese E., Graham, Lisa, Kostin, David, and Shulman, David. (1993). Real Estate Market Review, New York: Salomon Brothers, Inc.

Glascock, John L. (1991), "Market Conditions, Risk, and Real Estate Portfolio Returns: Some Empirical Evidence," Journal of Real Estate Finance and Economics, 4(4), 367-373.

Glascock, John L., Davidson, Wallace N., and Sirmans, C.F. (1989). "An Analysis of the Acquisition and Disposition of Real Estate Assets," Journal of Real Estate Research, 4(3), 131-140.

Glascock, John L., Davidson, Wallace N., and Sirmans, C.F. (1991). "The Gains from Corporate Selloffs: The Case of Real Estate Assets," AREUEA Journal, 19(4), 567-582.

Glascock, John L., and Hughes, William T. (1993). "NAREIT Identified Exchange Listed REITs and Their Performance Characteristics, 1972-1991," working paper, Louisiana State University.

Goebel, Paul R., and Kim, Kee S. (1989). "Performance Evaluation of Finite-Life Real Estate Investment Trusts," The Journal of Real Estate Research, 4(2), 57-69.

Goebel, Paul R., and Ma, Christopher K. (1993). "Stock Returns and Business Performance in REITs," working paper, Texas Tech University.

Goetzmann, William N., and Ibbotson, Roger G. (1990). "The Performance of Real Estate as an Asset Class," Journal of Applied Corporate Finance, 13(1), 65-76.

Golz, Gregory L. (1993). “The Compensation of REIT CEOs Provides Inadequate Incentives,” Real Estate Review, 23(2), 7-10.

Gunterman, Karl L., and Smith, Richard L. (1987). "Derivation of Cost of Capital and Equity Rates From Market Data," AREUEA Journal, 15(2), 98-109.

Gyourko, Joseph, and Linneman, Peter. (1988). "Owner-Occupied Homes, Income-Producing Properties, and REITs as Inflation Hedges: Empirical Findings,” Journal of Real Estate Finance and Economics, 1(4), 347-372.

Gyourko, Joseph, and Keim, Donald B. (1992). "What Does the Stock Market Tell Us About Real Estate Returns?," AREUEA Journal, 20(3), 457-485.

Haight, G. Timothy, and Ford, Deborah Ann. (1987). REITs, New Opportunities in Real Estate Investment Trust Securities, Chicago: Probus Publishing Company.

Han, Jun. (1991). "The Return-Generating Process of Real Estate Investment Trusts," working paper, MIT.

Han, Jun. (1990). "Did REITs Really Outperform the Stock Market Portfolio?," working paper, MIT.

Hartzell, David J., and Mengden, Anne E. (1987). Another Look at Equity Real Estate Investment Trust Returns, New York: Salomon Brothers, Inc.

Howe, John S., and Shilling, James D. (1988). "Capital Structure Theory and REIT Security Offerings," Journal of Finance, 43(4), 983-993.

Howe, John S., and Shilling, James D. (1990). “REIT Advisor Performance," AREUEA Journal, 18(4), 479-499.

Hsieh, Cheng-Ho, and Sirmans, C.F. (1991). "REITs as Captive-Financing Affiliates: Impact on Financial Performance," The Journal of Real Estate Research, 6(2), 179-189.

Jarchow, Stephen P. (1988). Real Estate Investment Trusts, New York: John Wiley \& Sons.

Jaffe, Jeffrey F. (1991). "Taxes and the Capital Structure of Partnerships, REITs, and Related Entities," Journal of Finance, 46(1), 401-408.

Jenkins, James W. (1980). "Incentive Compensation and REIT Financial Leverage and Asset Risk," Financial Management, 9(1), 81-87.

Khoo, Terence, Hartzell, David, and Hoesli, Martin. (1993). "An Investigation of the Change in Real Estate Investment Trust Betas," AREUEA Journal, 21(2), 107-130.

Knight, Ray A., and Knight, Lee G. (1992). "REITs, Reemerge as Attractive Investment Vehicles," Real Estate Review, 22(2), 42-48.

Kuhle, James L. (1987). "Portfolio Diversification and Return Benefits-Common Stock vs. Real Estate Investment Trusts (REITs)," The Journal of Real Estate Research, 2(2), 1-9.

Kuhle, James L., and Moorehead, Josef D. (1988). "Selecting Fundamentally Sound Real Estate Investment Trusts," Real Estate Finance, 4(4), 39-42.

Kuhle, James L., and Walther, Carl H. (1986). "REIT vs. Common Stock Investments: An Historical Perspective," Real Estate Finance, 3(1), 47-52. 
Kuhle, James L., Walther, Carl H., and Wurtzebach, Charles H. (1986). "The Financial Performance of Real Estate Investment Trusts," The Journal of Real Estate Research, 1(1), 67-75.

Lee, Cheng F., and Kau, James B. (1987). "Dividend Payment Behavior and Dividend Policy on REITs," Quarterly Review of Economics and Business, 27(2), 6-21.

Lentz, George H., and Stern, Jerold J. (1991). "Restructuring Corporate Real Estate Holdings Using PTPs and REITs," Journal of the American Taxation Association, 13(2), 96-115.

Liang, Youguo, and Webb, James R. (1993). "Pricing Interest Rate Risk for Mortgage REITs," working paper, Cleveland State University.

LIang, Youguo, McIntosh, Willard, and Webb, James R. (1993). "Intertemporal Changes in the Riskiness of REITs," working paper, Cleveland State University.

Liu, Crocker H., Hartzell, David J., Greig, Wylie, and Grissom, Terry V. (1990). "The Integration of the Real Estate Market and the Stock Market: Some Preliminary Evidence," Journal of Real Estate Finance and Economics, 3(3), 261-282.

Liu, Crocker H., Hartzell, David J., and Grissom, Terry V. (1992). "The Role of Coskewness in the Pricing of Real Estate," Journal of Real Estate Finance and Economics, 5(3), 299-319.

Liu, Crocker H., and Mei, Jianping. (1992a). "The Predictability of Returns on Equity REITs and Their CoMovement with Other Assets," Journal of Real Estate Finance and Economics, 5(4), 401-418.

Liu, Crocker, and Mei, Jianping. (1992b). "An Analysis of Real Estate Risk Using the Present Value Model," Journal of Real Estate Finance and Economics, forthcoming.

Liu, Crocker H., and Mei, Jianping. (1993). "Evidence on the Integration of International Real Estate Markets and Diversification Consequences," working paper, New York University.

Lynn, Theodore S., Goldberg, Harry F., and Steinfeld, Robert H. (1987). Real Estate Investment Trusts, Paramus N.J.: Prentice Hall Information Services.

Maris, Brian A., and Elayan, Fayez A. (1990). "Capital Structure and the Cost of Capital For Untaxed Firms: The Case of REITs," AREUEA Journal, 18(1), 22-39.

Maris, Brian A., and Elayan, Fayez A. (1991). "A Test for Tax-Induced Investor Clienteles in Real Estate Investment Trusts," The Journal of Real Estate Research, 6(2), 169-178.

Martin, John D., and Cook, Douglas O. (1991). "A Comparison of the Recent Performance of Publicly Traded Real Property Portfolios and Common Stock," AREUEA Journal, 19(2).

McIntosh, Willard. (1991). "The Effect of Poison Pill Securities on REIT Stock Prices," Real Estate Issues, 16(1), 34-38.

McIntosh, Willard, Liang, Youguo, and Tompkins, Daniel L. (1991). "An Examination of the Small Firm Effect within the REIT Industry," The Journal of Real Estate Research, 6(1), 9-17.

McIntosh, Willard, Officer, Dennis T., and Born, Jeffrey A. (1989). "The Wealth Effects of Merger Activities: Further Evidence from Real Estate Investment Trusts," The Journal of Real Estate Research, 4(3), 141-155.

McIntosh, Willard, Ott, Steven H., and Liang, Youguo. (1993). "The Wealth Effects of Real Estate Transactions: The Case of REITs," working paper, University of Kentucky.

McIntosh, Willard, Rogers, Ronald C., Sirmans, C.F., and Liang, Youguo. (1992). "Stock Price Management Changes: The Case of REITs," AREUEA Journal, forthcoming.

McIntosh, Willard, and Zaman, MIr A. (1992). "REITs and Insider Activity," working paper, University of Iowa.

Mengden, Anne E. (1988). Real Estate Investment Trusts-Sensitivity of Dividend Yields to Changes in Interest Rates, New York: Salomon Brothers, Inc.

Mengden, Anne E., and Hartzell, David J. (1986). Real Estate Investment Trusts-Are They Stocks or Real Estate?, New York: Salomon Brothers, Inc.

Miles, Mike. (1990). "What Is the Value of All U.S. Real Estate?," Real Estate Review, 20(2), 69-77.

Miles, Mike, and McCue, Tom (1982). "Historic Returns and Institutional Real Estate Portfolios," AREUEA Journal, 10(2), 184-199.

Murphy, J. Austin, and Kleiman, Robert T. (1989). "The Inflation-Hedging Characteristics of Equity REITs: An Empirical Study," Quarterly Review of Economics and Business, 29(3), 95-101.

Myer, F.C. Neil, and Webb, James R. (1993a). "Return Properties of Equity REITs, Common Stocks, and Commercial Real Estate: A Comparison,” Journal of Real Estate Research, 8(1), 87-106.

Myer, F.C. Neil, and Webb, James R. (1993b). "Retail Stocks, Retail REITs, and Retail Real Estate," Journal of Real Estate Research, forthcoming.

Myer, F.C. Neil, and Webb, James R. (1990). "REIT Returns and Economic News," working paper, Cleveland State University.

Myers, Stewart C., and Majluf, Nicholas S. (1984). "Corporatae Financing and Investment Decisions When Firms Have Information That Investors Do Not Have,' Journal of Financial Economics, 13(2), 187-221.

National Association of Real Estate Investment Trusts 1993. REIT Watch, (February), Washington, D.C. 
Page, Daniel E. (1993). “Criteria for Investment Decision Making: An Empirical Study,” Appraisal Journal, 51(4), 498-508.

Palmon, Don, and Seidler, Lee J. (1978). "Current Value Reporting of Real Estate Companies and a Possible Example of Market Inefficiency," The Accounting Review, 53(3), 776-790.

Patel, Raman, C., and Olsen, Robert A. (1984). "Financial Determinants of Systematic Risk in Real Estate Investment Trusts, Journal of Business Research, 12(3), 481-491.

Park, Jeong Yun, Mullineaux, Donald J., and Chew, It-Keong. (1990). “Are REITs Inflation Hedges?," Journal of Real Estate Finance and Economics, 3(1), 91-103.

Quan, Daniel, C., and Quigley, John M. (1991). "Price Formation and the Appraisal Function in Real Estate Markets," Journal of Real Estate Finance and Economics, 4(2), 127-146.

Quinn, Jane Bryant. (1987). "After the Crash, Some Stockbrokers Expose Real Estate Investment Trusts," The Atlanta Journal and Constitution, November 16, 1987.

Ross, Stephen A., and Zisler, Randall C. (1987a). Managing Real Estate Portfolios Part 2: Risk and Return in Real Estate, New York: Goldman Sachs.

Ross, Stephen A., and Zisler, Randall C. (1987b). Managing Real Estate Portfolios Part 3: A Close Look at Equity Real Estate Risk, New York: Goldman Sachs.

Ross, Stephen A., and Zisler, Randall C. (1991). "Risk and Return in Real Estate," Journal of Real Estate Finance and Economics, 4(2), 175-190.

Sagalyn, Lynne B. (1990). "Real Estate Risk and the Business Cycle: Evidence from Security Markets," The Journal of Real Estate Research, 5(2), 203-219.

Scott, Louis O. (1990). “Do Prices Reflect Market Fundamentals in Real Estate Markets?,” Journal of Real Estate Finance and Economics, 3(2), 5-23.

Shilling, James D., Do, A. Quang, and Sirmans, C.F. (1989). "Indirect Bankruptcy Costs and Voluntary REIT Liquidations," working paper, Louisiana State University.

Shilling, James D., Sirmans, C.F., and Wansley, James D. (1986). "Do REIT Shares Trade At a Discount? Some Indirect Evidence," working paper, Louisiana State University.

Shilling, James D., Sirmans, C.F., and Wansley, James W. (1986). "Tests of the Informational Content of Dividend Announcements When Dividend Policy Is Constrained: The Case of REITs," working paper, Louisiana State University.

Smith, Keith V., and Shulman, David. (1976). "The Performance Record of the Equity REITs," Finance Analyst Journal, 32(5), 61-66.

Solt, Michael E., and Miller, Norman G. (1985). "Managerial Incentives: Implications for the Financial Performance of Real Estate Investment Trusts,” AREUEA Journal, 13(4), 404-423.

Titman, Sheridan, and Warga, Arthur. (1986). "Risk and the Performance of Real Estate Investment Trusts: A Multiple Index Approach," AREUEA Journal, 14(3), 414-431.

Vines, Timothy W., Hsieh, Cheng-Ho, and Hatern, John J. (1993). "The Role of Systematic Covariance and Coskewness in the Pricing of Real Estate: Evidence from Equity REITs," working paper, Louisiana State University in Shreveport.

Wang, Ko, Erickson, John, and Gau, George W. (1993), "Dividend Policies and Dividend Announcement Effects for Real Estate Investment Trusts," AREUEA Journal, 21(2), 185-201.

Wang, Ko, Erickson, John, Gau, George, and Chan, Su Han. (1992). "Market Microstructure and Real Estate Returns," working paper, California State University-Fullerton.

Webb, James R., and McIntosh, Willard. (1986). "Real Estate Investment Acquistion Rules for REITs: A Survey," The Journal of Real Estate Research, 1(1), 77-98.

Wofford, Larry E., and Moses, Edward A. (1978). "Relationship Between Capital Markets and Real Estate Investment Yields: The Theory and Application," The Real Estate Appraiser and Analyst, 44(6), 51-61. 